\title{
Stare druki i ich udostępnianie
}

U dostępnianie, które jest najważniejszym celem istnienia i działania bibliotek, naraża książkę na zniszczenie, zwłaszcza książkę zabytkową. Stare druki należą do zbiorów muzealnych, stąd konieczność większej ich ochrony. Ponadto wartość rynkowa starych druków naraża je na kradzieże. $Z$ tych powodów wynikają dla bibliotekarzy zatrudnionych $w$ działach udostępniania zbiorów specjalnych, w tym starych druków, szczególne zadania odmienne od praktyki udostẹpniania zbiorów ogólnych. Ta specyfika udostępniania oraz doświadczenia zdobyte w czytelni starych druków Biblioteki Uniwersyteckiej we Wrocławiu podyktowały temat tej pracy.

Stare druki mają wspólne problemy z częścią innych zbiorów specjalnych, przede wszystkim $\mathrm{z}$ tymi partiami zbiorów, które określamy jako druki rzadkie i cenne. Dlatego zajmujemy się także pojęciem cymeliów w bibliotekach i praktyką biblioteczną z nimi związaną. Problemy udostępniania starych druków przedstawimy na przykładzie wybranych polskich bibliotek naukowych. Wyboru bibliotek dokonaliśmy kierując się wielkością zasobów starych druków w poszczególnych bibliotekach. Posłużyliśmy się zestawieniem przygotowanym przez Bibliotekę Narodową dla uczestników roboczej konferencji, która odbyła się 23-24 lutego 1978 roku. Dane te są więc sprzed lat 19, wiemy jednak, że nie uległy one zasadniczym zmianom, ponieważ zbiory starych druków, jeśli w ogóle rosna, to bardzo powoli i rocznie przybywa ich do poszczególnych oddziałów niewielka ilość, co nie zmienia ogólnego obrazu zasobów. ${ }^{1} \mathrm{Za}$ mierzeniem autorki jest przedstawienie problemów, które rodzą się w praktyce udostępniania starych druków na podstawie doświadczeń własnych oraz 16 innych, największych pod względem zasobów starych druków bibliotek polskich. Wybrano biblioteki posiadające co najmniej 20000 woluminów starych druków i przeprowadzono w nich ankietę z zakresu interesującego nas zagadnienia. Dwie Biblioteki: Uniwersytecka w Łodzi oraz Śląska w Katowicach nie odpowiedziały na ankietę.

Aby omówić, w oparciu o analizę odpowiedzi na ankietę, organizację udostępniania starych druków w bibliotekach polskich i związanych

Z Badan Nad Polskimi Księgozbiorami Historycznymi, t. 18, Warszawa 1997 
z tym problemów, autorka przedstawi i ustosunkuje się do terminologii księgoznawczej w zakresie pojęć „zbiory specjalne”, „stare druki”, „cymelia”. Problematyka zbiorów rzadkich i cennych w ogóle, a w dalszej kolejności cymeliów, już tylko w obrębie oddziałów starych druków jest szczególnie interesująca. Zatem zagadnienie gromadzenia, ochrony i zabezpieczenia cymeliów omówione zostanie szczegółowo. Autorka podjęła także - w oparciu o dostępne opracowania - próbę porównania doświadczeń Polski i innych krajów w zakresie tej problematyki. Krótkie charakterystyki zbiorów specjalnych ze szczególnym uwzględnieniem historii księgozbiorów poszczególnych bibliotek naukowych omawiane są zwykle $w$ informatorach wydawanych przez te biblioteki. ${ }^{2}$ Także polskie czasopisma bibliotekarskie oraz wydawnictwa seryjne, choć już o wiele rzadziej przybliżają nam poszczególne kolekcje. ${ }^{3}$ Natomiast problematyka struktury organizacyjnej i zadań tych działów niezwykle rzadko poruszana jest na łamach polskich czasopism bibliotekarskich. Od czasu do czasu pojawiają się wydawnictwa będące plonem konferencji zajmujących się sprawami zbiorów specjalnych, ich struktury i zadan. ${ }^{4}$ Natomiast problematyka udostępniania zbiorów specjalnych, a w szczególności starych druków nie cieszy się większym zainteresowaniem badaczy. ${ }^{5}$ Nie była także dotąd poruszana na łamach polskich czasopism bibliotekarskich, tj.: Przegladu Bibliotecznego, Roczników Bibliotecznych czy Rocznika Biblioteki Narodowej. Jeśli pojawiają się jakieś publikacje odnośnie udostępniania, to dotyczą przede wszystkim bibliotek publicznych. Z udostępnianiem starych druków związana jest kwestia ich bezpieczeństwa, ochrony przed kradzieżą i zniszczeniem. Tym problemem polskie czasopisma bibliotekarskie się nie zajmuja. ${ }^{6}$ Nie inaczej przedstawia się sytuacja $w$ piśmiennictwie zagranicznym. Tam jednak inna jest struktura zbiorów specjalnych, ponieważ inne jest rozumienie pojęcia "zbiory specjalne". Większość zagranicznych słowników bibliotekarskich nie uwzględnia nawet tego pojęcia, nie wyjaśnia więc też jego znaczenia. Nie wydziela się też za granicą odrębnych oddziałów starych druków, co najwyżej istnieją oddziały rękopisów i inkunabułów, ale najczęściej działy książek rzadkich i cennych. Pojęcie „cimelium” rozumiane jest bardzo szeroko zarówno ze względu na kryterium formalne jak i czasowe, stąd struktura oddziałów książek rzadkich i cennych jest tam odmienna niż w Polsce. Większość artykułów i publikacji książkowych za granica omawia poszczególne kolekcje zbiorów rzadkich i cennych. ${ }^{7} \mathrm{O}$ wiele rzadziej poruszane są problemy ochrony tych zbiorów przed kradzieża 
i zniszczeniem. Ostatnio dużo jest głosów odnoszących się do oszczędzania tych zbiorów przez udostępnianie mikrofilmów zamiast oryginałów w wypadkach, gdy chodzi tylko o treść dzieła. Z tym łączy się problem udoskonalenia technik mikrofilmowania, tak aby nie powodowaty one uszkodzeń oryginałów $\mathrm{w}$ trakcie filmowania. ${ }^{8}$ Nikt jednak szczegółowo nie zajmował się $\mathrm{w}$ piśmiennictwie zagranicznym, dostępnym $\mathrm{w}$ Polsce, problemami udostępniania zbiorów specjalnych a w szczególności starych druków. Artykuł niniejszy jest próbą przedstawienia problemów związanych $z$ udostępnianiem tych zbiorów. Należy jednak podkreślić, że dane liczbowe odnoszą się do czasu przeprowadzonej ankiety, tj. do 1978 ro$\mathrm{ku}$. Również formy udostępniania starych druków wypracowane $\mathrm{w}$ poszczególnych polskich bibliotekach naukowych odnoszą się do tego samego okresu. Jedynie w przypadku Biblioteki Uniwersyteckiej we Wrocławiu poszerzono także informacje o dane z 1993 roku.

Pojęcie „zbiory specjalne” funkcjonuje w bibliotekarstwie już od połowy XIX w., kiedy to pojawiły się koncepcje wyodrębniania $z$ ogólnych zbiorów bibliotecznych pewnych zespołów obiektów ze względu na ich cechy formalne. Były to najpierw zbiory szczególnie rzadkie i cenne tzw. „rara" wywodzące się z XVIII-wiecznych ,gabinetów starożytności” oraz „cymelia” - druki od XVI w. do czasów współczesnych, często o charakterze muzealnym a ponadto rękopisy, najstarsze druki - inkunabuły oraz zbiory kartograficzne, ikonograficzne i muzyczne. Te ostatnie wyodrębniono w bibliotekach najpóźniej, bo dopiero w początkach $\mathrm{XX}$ w. ${ }^{9}$ Bardzo zwięźle definiują termin „zbiory specjalne” $H$. Więckowska i H. Pliszczyńska w Podręcznym słowniku bibliotekarza z 1955 r., a mianowicie są to: ,[...] $w$ bibliotece zbiory pozaksiqżkowe, jak muzyczne, graficzne, kartograficzne”; także: „zbiory specjalne cerme lub niezwy$k t e{ }^{10}{ }^{10} \mathrm{~W}$ miarę upływu czasu pojęcie zbiorów specjalnych rozszerzyło się i objęło nowe typy gromadzonych przez bibliotekę dokumentów, tj.

1. materiały uzyskane metodami reprograficznymi czy fonograficznymi, np. mikrofilmy, fotokopie, mikrofisze, płyty, taśmy magnetofonowe;

2. dokumenty życia społecznego, gospodarczego czy technicznego np. ulotki, afisze, programy teatralne, kinowe, księgi adresowe i telefoniczne, rozkłady jazdy, cenniki, katalogi, normy, patenty.

$\mathrm{Na}$ wyodrębnienie tych nowych typów dokumentów wpływają cechy formalne, a w przypadku dokumentów życia społecznego: doraźność informacji, nikłość problematyki. Cechą wspólną zbiorów specjalnych, tych tradycyjnych i nowego typu, jest potrzeba innych, odrębnych, wła- 
ściwych dla każdego gatunku metod opracowania bibliotecznego. Na ten właśnie warunek zwrócili uwagę W. Mincer i $\mathrm{K}$. Podlaszewska, którzy $\mathrm{w}$ artykule Zbiory specjalne jako warsztat pracy naukowej definiują zbiory specjalne jako ,zespoty dokumentów wyłaczonych z ogólnego zasobu dokumentów bibliotecznych ze względu na ich odrebne cechy formalne oraz inna metode opracowania bibliotecznego". ${ }^{11}$ Przy czym termin "opracowanie biblioteczne" ujęto $\mathrm{w}$ bardzo szerokim znaczeniu jako opracowanie, przechowywanie i udostępnianie zbiorów. Najbardziej aktualny obecnie słownik polskiej terminologii bibliotekarskiej, Encyklopedia wspótczesnego bibliotekarstwa polskiego, określa zbiory specjalne jako ,zespoly obiektów wydzielone z ogólnych zbiorów bibliotecznych ze względu na ich odrębne cechy formalne, osobno magazynowane, specjalnie opracowywane i udostępniane" ${ }^{12} \mathrm{~W}$ dalszej części definicji wymienia się typy dokumentów zaliczanych do zbiorów specjalnych. Podkreśla się też zabytkowy i unikatowy charakter części tych zbiorów, ich wartość jako dokumentów źródłowych gromadzonych w celach historyczno-badawczych lub dokumentacyjnych. W tej dość szerokiej definicji encyklopedycznej nie wyjaśnia się już szczegółowo praktyki wyodrębniania zbiorów specjalnych w bibliotekach innych krajów. Definicja zbiorów specjalnych [Sondersammlung] w Lexikon des Bibliothekswesens wyraźnie rozszerza pojęcie zbiorów specjalnych jako część wyłączoną ze zbiorów ogólnych po zastosowaniu specjalnych kryteriów formalnych i kryteriów treściowych ${ }^{13}$ Przykładowo wymienia się zbiory specjalne właściwe tylko dla wybranej biblioteki jak zbiór literatury emigracyjnej 1933-1945 w Deutsche Bücherei w Lipsku. We wspomnianej definicji autor hasła H. Roloff zwraca także uwagę na pewien szczególny typ zbiorów specjalnych, popularny w bibliotekach angielskich $i$ amerykańskich, jakimi sa prywatne kolekcje zbieraczy, często jako stały depozyt właczone do zbiorów bibliotecznych. $W$ bibliotekarstwie niemieckim przykładem tej kategorii zbiorów specjalnych może być kolekcja druków zgromadzona przez drezdeńskiego księgarza Heinricha Klemma, która utworzyła podwaliny Deutsche Buch- und Schriftmuseum przy Deutsche Bücherei, czy zbiór dzieł Dantego zgromadzony przez Friedricha Schneidera dziś w Deutsche Staatsbibliothek w Berlinie. Natomiast Harrod's librarians' glossary of terms used in librarianship... definiuje pojęcie „special collection” jako ,zbiór ksiqzek zwiqzanych z lokalnq historiq, osobistosciami, uprzemystowieniem itp., alho na pewien temat cay okres czasu,

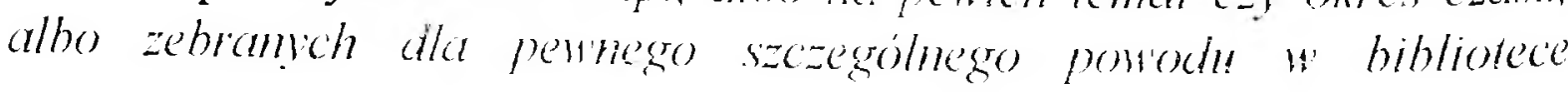


o charakterze ogólnym". ${ }^{14}$ Zgodnie $\mathrm{z}$ tą definicją przy wydzielaniu zbioru specjalnego, kryterium treściowe jest decydujące. W słowniku Margarety Rehm: Lexikon Buch. Bibliothek. Neue Medien nie ma wprawdzie hasła "Sondersammlung” ale jest „sondermagazin”. Jest to: „w bibliotekach naukowych część zbiorów wydzielona z magazynu ogólnego i przechowywana $w$ oddzielnym magazynie dla większego ich bezpieczeristwa oraz zachowania. Tworzy się magazyn specjalny dla rękopisów, inkunabulów, zbiorów rzadkich, map, literatury tajnej". ${ }^{15}$

W pozostałych zagranicznych leksykonach bibliotekarskich nie znajdziemy hasła „zbiory specjalne”. Tak jak różnie pojmowano biblioteczne zbiory specjalne, różne też przyjęto rozwiązania organizacyjne. Przykłady odmiennych rozwiązań organizacyjnych wielkich bibliotek za granica podaje J.Z. Lichański. ${ }^{16} \mathrm{~W}$ Polsce dla przykładu podajemy organizację Działu Zbiorów Specjalnych Biblioteki Narodowej w Warszawie. Dział ten w swej obecnej postaci uformował się po II wojnie światowej, a obecny kształt uzyskał w wyniku nadania Bibliotece Narodowej nowego statutu w 1969 r. W skład Działu Zbiorów Specjalnych wchodzą: Zakład Starych Druków, Zakład Rękopisów, Zakład Zbiorów Ikonograficznych, Zakład Zbiorów Kartograficznych, Zakład Zbiorów Muzycznych, Pracownia Dokumentów Dźwiękowych, Zakład Zbiorów Mikrofilmowych oraz Oddział Udostępniania Zbiorów Specjalnych. ${ }^{17}$ Dodajmy, że Pracownia Dokumentów Dźwiękowych została wyodrębniona z Zakładu Zbiorów Muzycznych w 1982 roku. Zadaniem jej jest gromadzenie, opracowanie a w przyszłości, udostępnianie dokumentów dźwiękowych. Natomiast w Bibliotece Uniwersyteckiej w Poznaniu utworzono odrębne oddziały: Starych Druków oraz Zbiorów Specjalnych; ten ostatni z siedmioma sekcjami i pracowniami, tj.: Sekcją Zbiorów Kartograficznych, Sekcją Zbiorów Muzycznych, Sekcją Rękopisów, Sekcją Dokumentów Życia Społecznego, Pracownią Pamiętnikarska, Pracownią Ikonograficzną Pracownią Mikroform. Odrębne oddziały starych druków istnieją także w Bibliotece Uniwersyteckiej we Wrocławiu, w Bibliotece Uniwersyteckiej w Warszawie, w Bibliotece Zakładu Narodowego im. Ossolinskich we Wrocławiu. W innych większych bibliotekach zbiory rękopisów i starych druków tworzą wspólny oddział np. w Bibliotece Uniwersyteckiej w Toruniu czy też w Bibliotece Gdańskiej PAN.

Stare druki określane są w Encyklopedii wiedzy o ksiqżce następująco: "Publikacje z okresu od wynalezienia druku do konca XVIII w.

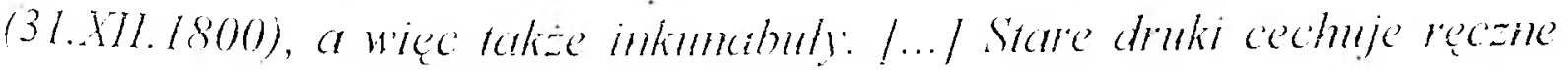


wytwarzanie wszystkich ich składników: papieru, typografii ew. ilustracji $i$ oprawy". ${ }^{18} \mathrm{~W}$ całym świecie przyjmuje się rok 1800 jako datę końcową starych druków; wyjątkiem jest Anglia, gdzie granicą jest rok 1640. Zasób starych druków jest obecnie w każdym państwie wielkością stałą prawie niezmienna, wymierną $w$ liczbach pod względem ilości woluminów, a ich wartość materialna, trudna do ocenienia, stanowi kulturalne mienie narodu. W literaturze księgoznawczej jest wiele definicji pojęć „cymelia”, „rara”, „unikat” oraz wiele prób wprowadzenia wśród nich logicznego porządku, ale jak dotąd są one pelne subiektywnych sądów. Encyklopedia wspótczesnego bibliotekarstwa polskiego przytacza definicję: "Cimelia (rara), sq to cenne i rzadkie obiekty biblioteczne, majace wartość muzealnq zazwyczaj wydzielone z ogólnych zasobów ze względu na konieczność specjalnej ich ochrony, udostępniane na szczególnych warunkach (często w postaci fotokopii lub mikrofilmui). Do cimeliów należa rękopisy i inkunabuty, pierwsze edycje dziel klasyków, wytwory stawnych oficyn drukarskich, zabytki sztuki introligatorskiej i edytorskiej, zbiory o stawnej proweniencji, np. egzemplarze pochodzqce z księgozbiorów królewskich, magnackich, znakomitych pisarzy lub naukowców i wszelkie unikaty". ${ }^{19}$ Dla uzupełnienia tej definicji dodać należy jeszcze wyjaśnienie terminu unikat: ,jedyny zachowany egzemplarz dziela; dzielo wytloczone $w$ jednym egzemplarzu. bo inne wraz z odbitkami koreklowymi zostały celowo zniszczone; egzemplarz ozdobiony ręcznie albo odmiennym sposobem, co różni go od innych egzemplarzy z tego samego nakladu; egzemplarz ze specjalnymi dodatkami jak autografem autora lub oryginalnymi rysunkami, cennymi marginaliami; wszelkie obiekty cenne ze wzglęch na swa wartość merytoryczna lub zabytkowq wykonane ręcznie (rękopis, autograf dzieła, rysunek)". ${ }^{20}$ Problemy bibliotekarstwa książek rzadkich i opieki nad zbiorami specjalnymi były często poruszane na łamach fachowych periodyków zagranicznych, ale jak dotąd nie było satysfakcjonującej pracy traktującej o przedmiocie jako całości. Jedną z nielicznych jest skrypt z wykładów uniwersyteckich na Uniwersytecie w Loughborough Rodericka Cave'a: Rare Book Librarianship. ${ }^{21}$ Autor porusza wszystkie problemy związane z książą rzadką od gromadzenia poprzez opracowanie (katalog alfabetyczny i rzeczowy), konserwacje, magazynowanie, organizację udostępniania zbiorów rzadkich, reklamę i publikacje dotyczące tych zbiorów czy wreszcie kształcenie bibliotekarzy specjalistów w tym zakresie. W rozdziale I! The nathe of the rare hook przytacza szereg definicji ksiązi rzacikicj funkcjonujących juz od XVII! w. Następ- 
nie powołuje się na Johna Cartera, wykładowcę w Cambridge, który opublikował swoje wykłady $\mathrm{w}$ pracy pt. Taste and technique in book collecting wydana w Cambridge w 1948 r. i wznowiona w 1970 r. Wylicza za Carterem kilka różnorodnych czynników związanych z kolekcjonowaniem i oszacowaniem książki rzadkiej. Ale również Cave nie precyzuje jednoznacznej definicji książki rzadkiej.

W związku z istnieniem tak wielu różnych definicji cymeliów, tworzone w bibliotekach zagranicznych oddziały książki rzadkiej, mają różną strukturę. Dla lepszego zobrazowania tego zagadnienia przedstawić trzeba organizację Sekcji Cennych Rezerw (Réserve Précieuse) w Bibliotece Królewskiej w Brukseli, Oddziału Książki Rzadkiej (The Rare Book Division) w Bibliotece Kongresu w Waszyngtonie, oddziału rzadkich książek (otdel redkich knig) w Rosyjskiej Państwowej Bibliotece w Moskwie oraz Oddziału druków rzadkich i cennych (Die Abteilung der seltene und kostbare Drucke) w Niemieckiej Państwowej Bibliotece w Berlinie.

Sekcję Cennych Rezerw w Bibliotece Królewskiej w Brukseli częściowo można utożsamiać z sekcja starych druków polskiej biblioteki naukowej. ${ }^{22}$ Do tego zbioru cymeliów należą wszystkie inkunabuły (ok. 3000), z druków szesnastowiecznych wszystkie do roku 1540, z lat 1541-1600 tylko belgica, wszystkie książki drukowane w Anglii do r. 1640, druki muzyczne do 1700 r. oraz wszystkie druki późniejsze aż do naszych czasów, jeśli są piękne, rzadkie lub dotyczą historii książki. Selekcja druków uwzględnia historię drukarstwa, ilustracji, opraw a także rzadkość edycji, wage proweniencji. Obecnie sekcja ta posiada ok. 35000 druków. W dziale tym znajduje się także m.in. wyselekcjonowany wybór książek ilustrowanych przez wielkich artystów XX w., stare druki dotyczące nauk prawa zwyczajowego belgijskiego, historii Belgii, historii nauk, literatury niderlandzkiej, muzykologii. Rękopisy nie wchodzą w skład cymeliów, tworzą oddzielną sekcję w Bibliotece Królewskiej.

Zupełnie inna jest struktura Oddziału Książki Rzadkiej w Bibliotece Kongresu w Waszyngtonie. Pod opieką tego oddziału znajduje się 350000 pozycji od średniowiecza do współczesności i reprezentuja one wszystkie dyscypliny nauki. Są to rękopisy, książki, ulotki. ${ }^{23}$ Charakterystyczne, że prywatne kolekcje książek przekazywane w darze Bibliotece Kongresu były zwykle włączane w całości do oddziału książki rzadkiej, np. darowana w początkach XX w. biblioteka J.B. Thachera wniosła 
cenne inkunabuły reprezentujące ponad 500 różnych drukarń ze 128 miast europejskich ale także wczesne americana i książki o Krzysztofie Kolumbie, książi o Rewolucji Francuskiej i autografy europejskie. W oddziale tym znajdują się także materiały nie książkowe, jak np. maska Abrahama Lincolna czy talerze deserowe, na których namalowany jest Kipling, dodane do kolekcji dla przechowywania z książkami, z którymi były one związane. Wśród innych zbiorów należących do oddziału książki rzadkiej wymienić trzeba średniowieczne i renesansowe rękopisy, materiały odnoszące się do życia i twórczości angielskich pisarzy, np. R. Kiplinga, H. Jamesa, W. Whitmana oraz zbiór 15000 woluminów amerykańskiej literatury młodzieżowej od początku XVIII w. do czasów współczesnych. Pojęcie cymeliów jest więc w Bibliotece Kongresu rozumiane bardzo szeroko. Autorzy przewodnika po Bibliotece Kongresu próbują odpowiedzieć na pytanie "Co to jest książka rzadka?", gdyż kwestia ta jest często podnoszona przez gości odwiedzających tę Bibliotekę oraz czytelników. Stwierdzają, że: "Z definicji ksiqżkami rzadkimi sq dzieła niepospolite wyróżniajace się swoja zawartościa lub cechami fizycznymi, z powodu których należy im się większa opieka ze strony kolekcjonerów ksiqżek, bibliotekarzy, uczonych i księgarzy. Ale ani sama rzadkość, ani wiek tylko, nie decyduja o wartości ksiażki, gdyż jest tysiqce rzadkich ksiqziek i tysiquce starych ksiazzek, które nie maja zadnej wartości. Gdy jednak ksiqżka posiadajaca jednq lub obydwie z tych cech, ma także inne wazne cechy, które sprawiaja, ze jest ona zarówno niezwykla jak interesujaca, wtedy moze ona być uważana za cennq". ${ }^{24}$ Dodają także, że jest wiele cech, które czynią książkę niezwykłą i interesująca. Z cech zewnętrznych wymieniaja piękną i szczególną oprawe, piękny kształt typograficzny czy ilustracje wykonane przez wybitnego sztycharza. Ponadto książki skądinąd pospolite zyskują na wartości przez to, że wcześniej były własnością znakomitych postaci historycznych. Autorzy przewodnika przyznaja, że określona przez nich definicja terminu „rare book” nie jest konsekwentnie przestrzegana w odniesieniu do Działu Książki Rzadkiej Biblioteki Kongresu, ponieważ przechowuje się w nim także książki, które nie są ani rzadkie, ani też szczególnie wartościowe. ${ }^{25}$

Organizacja oddziałów książki rzadkiej w państwach byłego Związku Radzieckiego jest odmienna. Problematyka cymeliów jest tam ostatnio bardzo popularna, o czym świadczą konforencje odbyte w ostatnich latach, poświęcone tej tematyce Rosylska Państwowa Biblioteka 
w Moskwie zorganizowała dwie wszechzwiązkowe konferencje, w 1979 r. i w 1980 r., z których pierwsza poświęcona była przechowywaniu i wykorzystywaniu rękopisów oraz zbiorów rzadkich i szczególnie cennych, druga zajmowała się zagadnieniem przechowywania zbiorów bibliotecznych a w szczególności przepisami przechowywania, restauracji i konserwacji materiałów rękopiśmiennych, drukowanych i opraw. Problem gromadzenia zbiorów rzadkich $w$ bibliotekach radzieckich szczegółowo omówił czołowy księgoznawca E.L. Nemirovskij. ${ }^{26}$ Stwierdził on, że planowemu gromadzeniu tych zbiorów przeszkadza szereg nie rozwiązanych dotąd problemów, a przede wszystkim księgoznawcy radzieccy nie przedstawili jeszcze precyzyjnego określenia pojęcia „rzadka książka”, choć podejmowano szereg takich prób. ${ }^{27}$ Obecnie u podstaw gromadzenia zbiorów oddziału rzadkich książek w Rosyjskiej Państwowej Bibliotece w Moskwie leżą dwie zasady: chronologiczna i tematyczna. Pierwsza formułuje precyzyjnie wszystkie rosyjskie książki, czasopisma, gazety od XVIXVIII w. i wszystkie zagraniczne od XV-XVIII w. Druga oparta jest na znaczeniu dzieła, roli jaką odegrało $w$ historii społeczno-politycznej myśli, nauki, literatury, sztuki. I tak przechowuje się pierwsze szczególnie cenne dzieła twórców marksizmu-leninizmu wydane za ich życia, wybitnych działaczy rewolucyjnego i robotniczego ruchu, wielkich pisarzy, uczonych, działaczy politycznych. Zbiera się i bada działa nielegalnego i rewolucyjnego drukarstwa, książki, czasopisma, gazety z okresu pierwszej rosyjskiej rewolucji 1905-1907 r., pierwszych lat władzy radzieckiej, z okresu wojny domowej. W dziale rzadkich książek gromadzi się także najlepsze współcześnie wydane książki o pięknej szacie graficznej i najbardziej charakterystycznych kierunkach sztuki typograficznej. Jednak wybór książek przy zachowaniu kryterium tematycznego jest często podyktowany czynnikami subiektywnymi, bo np. pojęcie "wybitny pisarz" może być różnie traktowane $w$ poszczególnych republikańskich, krajowych i obwodowych bibliotekach państw byłego Związku Radzieckiego. Nemirovskij postulował opracowanie dla tych bibliotek typowych profili gromadzenia w oddziałach rzadkich książek. ${ }^{28}$ Miałyby się tym zając dwie największe biblioteki: Rosyjska Państwowa Biblioteka w Moskwie i Publiczna Biblioteka im. Sałtykowa-Szczedrina w dawniejszym Leningradzie.

Oddział Druków Rzadkich i Cennych w Niemieckiej Państwowej Bibliotece w Berlinic powstat w 1075 r. i breją on juz istniejace a dotychczas znajdujące się pod opieką oddziału Inkunabułów zbiory: rara, druki 
o pięknej szacie typograficznej, zbiór pieśni nabożnych XVI i XVII w. uzyskanych $\mathrm{z}$ biblioteki bibliofila barona Meusebacha oraz zbiór ekslibrisów. ${ }^{29}$ Ponadto $\mathrm{w}$ dziale tym znajdują się druki stanowiące dziedzictwo kuturalne, literackie i naukowe od XVI w. do czasów współczesnych, o ile nie dotyczą innych zbiorów specjalnych, jak np. muzycznych, dzieła stanowiące spuściznę proletariacko-rewolucyjna np. pierwsze wydania dzieł klasyków marksizmu-leninizmu oraz całe kolekcje o dużym znaczeniu historyczno-naukowym i historyczno-kulturalnym otrzymane od instytucji i osób prywatnych. ${ }^{30}$ Pojęcie druków rzadkich i cennych ma bardzo szeroki zakres w Niemieckiej Państwowej Bibliotece w Berlinie. Problematyka cymeliów cieszy się także ogromnym zainteresowaniem u bibliotekarzy niemieckich, czego wyrazem sq liczne artykuły ogłaszane na łamach czasopism fachowych oraz zjazdy bibliotekarzy niemieckich poświęcone m.in. tej tematyce. ${ }^{31}$

W latach 1981-83 Wolfgang Dittrich z Wolfenbüttel, z Komisji Niemieckiego Instytutu Bibliotekoznawstwa do spraw Rękopisów i Starych Druków, opracował projekt zaleceń dotyczących zarządzania starymi i wartościowymi księgozbiorami i organizowania zbiorów unikalnych. ${ }^{32}$ On również nie daje jedynej obowiązującej definicji cymeliów, ale wymienia kryteria wyboru książek przeznaczonych do wydzielonego oddziału zbiorów rzadkich. Stwierdza tylko, że cymelia to ksiażki i inne materiały biblioteczne, których nadzwyczajna wartość i unikalny charakter wyróżniają od pozostałych dzieł znajdujących się w ogólnym księgozbiorze biblioteki. Stąd rękopisy i inkunabuły posiadają zasadniczo charakter unikalny. Jeśli chodzi o druki późniejsze, W. Dittrich wymienia kilka zasadniczych kryteriów pozwalających na określenie książki jako wartościowej:

1. druki ważne historycznie, naukowo i literacko,

2. druki ważne dla historii książki i sztuki książkowej,

3. egzemplarze ze szczególnymi cechami,

4. książki o wysokiej wartości rynkowej.

Jak wiemy tworzenie odrębnego oddziału książki rzadkiej jest zalecane w dużych bibliotekach ze względu na konieczność większej ich ochrony i wymogi konserwatorskie, jak również ze względu na potrzeby nauki. Zestawienie najwartościowszych dzieł w jednym stosunkowo przejrzystym zbiorze cymeliów stwarza możliwość lepszego kontrolowania stanu egzemplarzy $\mathrm{i}$ wprowadzenie $w$ razie konieczności niezbędnych środkow zaradczych (konserwatorskich, restauratorskich). Inaczej 
niż $\mathrm{w}$ wielkich ogólnych magazynach regularnie można dokonywać prostych prac pielęgnacyjnych, jak czyszczenie książek i regałów, natłuszczanie opraw skórzanych itp. Poza tym dzięki możliwości szybkiego dotarcia - w razie katastrofy - wzrasta szansa zachowania od strat najwartościowszych części zbioru. Ale z drugiej strony utworzenie odrębnego magazynu cymeliów rodzi pewne niebezpieczeństwa i nowe problemy wymagające przedsięwzięć organizacyjnych. Jak długo pojedyncze dzieła rzadkie tkwią w magazynie ogólnym w masie literatury użytkowej, mają one praktycznie pewną ochronę, która znika wraz z przeniesieniem ich do oddzielnego magazynu cymeliów. Pojawia się problem liczby osób, którym zezwala się na przekraczanie tego magazynu; powinna ona być maksymalnie ograniczona. Wstęp mogą mieć tylko ci, którzy mają zlecone opracowanie i opiekę nad tymi zbiorami. Ponadto książki przeniesione z ogólnego do szczególnie zabezpieczonego magazynu unikatów należy porządkować według dotychczasowej sygnatury uzupełniając o literę „C" czyli cymelia. Wprowadzenie nowej sygnatury wydaje się mało sensowne z powodu związanych z tym nakładów. Wszystkie te tytuły muszą być wskazane w głównym katalogu alfabetycznym, a w razie możliwości także w innych katalogach, np. rzeczowym, jako unikaty i opatrzone dopiskiem wskazującym na ograniczony charakter korzystania $z$ nich. Dla zachowania przejrzystości i umożliwienia kontroli zbiorów o każdej porze, niezbędny jest starannie prowadzony katalog miejscowy. Również ze względów bezpieczeństwa należy cymelia wykazywać w kilku miejscach, z których przynajmniej jedno nie jest udostępniane publiczności. Wyodrębnianie oddziałów książki rzadkiej, oprócz szeregu zalet, ma także wiele wad i rodzi nowe problemy do dyskusji.

$\mathrm{Na}$ gruncie polskim problematyka cymeliów ma zupełnie inny charakter, ponieważ w zasadzie $w$ polskich bibliotekach naukowych nie wyodrębnia się samodzielnych oddziałów książki rzadkiej. Do wyjątków należy Biblioteka Jagiellońska, która wyodrębniła zespół „Rara”, tj. rzadkie polskie druki XIX i XX w. Kategoria ta obejmuje m.in.: druki dotyczące powstań narodowych i Wielkiej Emigracji, pierwsze wydania klasyków literatury polskiej, polskie druki ulotne z okresu II wojny światowej, współcześnie wydawane poza granicami kraju polonica, niektóre druki wymagające szczególnego zabezpieczenia ze względu na ich atrakcyjność dla szerokiego kręgu czytelników (np. zespół druków dotyczących papieża Jana Pawła II) Natomiast w Biblintece Narodowej w skład oddziału starych drukow wchodzi kolckcja wianowsha, lacznie z hiąziati XIX 
i XX w. jako niepodzielny zespół muzealny. W ostatnich latach rozważana jest sprawa utworzenia w Bibliotece Narodowej Muzeum Książki. Prace nad jego koncepcją trwają od kilku lat, a niemożliwość ich sfinalizowania związana jest $\mathrm{z}$ trudnościami lokalowymi. Planowanie bowiem musi być dostosowane do określonych warunków lokalowych. J.Z. Lichański postuluje utworzenie Muzeum jako oddzielnego Działu Zbiorów Specjalnych, gdyż, jak sądzi, mogłoby się ono stać odpowiednikiem tego, co w bibliotekach innych krajów określa się mianem zbioru cymeliów czy rzadkiej książki. ${ }^{33}$ Oczywiście Muzeum Książki sięgałoby do zbiorów XIX i XX w. Sądzić należy, że w naszych warunkach tworzenie oddziałów książki rzadkiej dotyczyć może druków nowych, tj. XIX i XX w.

Osobnym problemem jest wyodrębnienie cymeliów w już wydzielonych oddziałach starych druków. Sięgnąc trzeba znów do przykładu Biblioteki Jagiellońskiej. Już K. Piekarski wyodrębnił wśród starych druków w tej książnicy kategorię „cymeliów”. Stanowią ją polonica XVI w., niektóre polonica XVII w., a także szczególnie cenne druki ze względu na proweniencję, np. fragment księgozbioru Zygmunta Augusta (druki obce), czy kolekcja książek hiszpańskich z biblioteki Piotra Dunin Wolskiego, biskupa płockiego. Zespół ten jest oznaczony odrębną sygnaturą (np. Cim.321). ${ }^{34}$

$\mathrm{Na}$ podstawie ankiety przeprowadzonej w 14 największych, pod względem ilości starych druków, bibliotekach polskich, stwierdzić można, że tylko w 4 spośród nich zostały wyodrębnione druki rzadkie tzw. cymelia i przechowuje się je w oddzielnych magazynach. O Bibliotece Jagiellońskiej już mówiliśmy. Ponadto, w Bibliotece Gdańskiej PAN wyodrębniono cymelia, do których wchodzą: księgozbiór fundatora biblioteki Jana Bernarda Bonifacio markiza Orii, inkunabuły oraz polonica XVI w. Cymelia te sa przechowywane w ramach magazynu starych druków i rękopisów, ale w wydzielonych miejscach i dodatkowo odrębnie opracowane. Natomiast w Bibliotece Muzeum Narodowego im. Czartoryskich w Krakowie zostały wyodrębnione cymelia i przechowuje się je wraz $\mathrm{z}$ inkunabułami $\mathrm{w}$ wydzielonym magazynie. $Z$ kolei $\mathrm{w}$ Bibliotece Kórnickiej PAN spośród starych druków wyodrębniono inkunabuły oraz polonica XVI w. (zwane są one cymeliami) i przechowuje się je oddzielnie. Natomiast w Bibliotece KUL są wydzielone tylko inkunabuły i przechowuje się je w zamkniẹtym magazynie, zaś w Wojewódzkiej i Miejskiej Bibliotece Publicznej w Szczecinie inlunabuly przechowuje się 
w szafach pancernych. W pozostałych bibliotekach cymelia są wyodrębnione $w$ bardzo niewielkim zakresie i przechowuje się je w szafach pancernych w magazynach oddziałów, np. w Bibliotece Uniwersyteckiej w Warszawie, w Bibliotece Uniwersyteckiej w Toruniu czy w końcu w Bibliotece Uniwersyteckiej we Wrocławiu. W tej ostatniej 114 najcenniejszych cymeliów przechowuje się w szafie pancernej. Szacuje się, że w Oddziale Starych Druków wrocławskiej Biblioteki Uniwersyteckiej jest ok. 20000 cymeliów (na ok. 310000 dziel), ale są one tylko częściowo zewidencjonowane. Prace $\mathrm{z}$ tym związane prowadzone były w latach 60-tych $w$ ramach prac zleconych i zostały przerwane $z$ powodu braku funduszów. Sądzimy, że jednym z najpilniejszych zadań na przyszłość oddziałów starych druków w Polsce będzie przeprowadzenie ewidencji cymeliów. Dopiero wówczas można będzie rozważać czy należy przechowywać je $w$ odrębnych magazynach i czy zapewni to lepsza ich ochronę. Bez względu na to, jakie rozwiązania organizacyjne przyjmą poszczególne biblioteki, uważamy, że ewidencja taka jest niezbędna. Ewidencja cymeliów przyczyni się do większej dbałości o stan zachowania tych druków poprzez prowadzenie w razie potrzeby konserwacji zapobiegawczej. Dla druków tych stworzy się lepsze warunki przechowywania w magazynie, ewentualnie wydzieli się dla nich odrębny magazyn. Ponadto ewidencja jest niezbędna dla systematycznego i planowego mikrofilmowania najcenniejszych druków; prace te zaś powinny być prowadzone równocześnie. Dopiero wówczas będzie można pomyśleć o racjonalnym gospodarowaniu zbiorami muzealnymi. Ewidencja druków rzadkich i cennych będzie także dostarczać wskazówek dla bibliotekarzy, kiedy szczególnie należy nadzorować czytelników. Pilnym zadaniem na przyszłość jest także przeprowadzenie ewidencji map i sztychów we wszystkich egzemplarzach starych druków, albo przynajmniej w najwartościowszej partii tych zbiorów, tj. drukach szczególnie rzadkich i cennych. Rejestracja cymeliów staje się problemem poszczególnych oddziałów, także oddziałów starych druków, na co wpływ ma struktura zbiorów w polskich bibliotekach. Ochrona cymeliów jest jedną z ważniejszych spraw do rozwiązania w udostępnianiu starych druków, o czym szczegółowo autorka pisze poniżej.

Z zabytkowego charakteru starych druków wynikaja dwa problemy w ich udostepnianiu: 1) jako obiekty zabytkowe stare druki powinny być chronione, 2) jak wszelkie inne zhiory muzealne czy dzieła sztuki posiadają one wartóś rynkowa, czasem wysoką, stąd bywają one 
przedmiotem lokaty kapitału. Zjawisko to szczególnie wzmaga się w momentach inflacji. W Polsce można było je obserwować od 1975 r., od czasu kryzysu naftowego, kiedy to ceny książek i dzieł sztuki gwałtownie wzrosły. Właściwość starych druków - bardzo wysoka i zróżnicowana cena, czasem nawet nie wiadomo jaka - powoduje, że stają się one celem zainteresowania złodziei-bibliofilów i różnego rodzaju spekulantów. Z tych też powodów problem ochrony ich stanu zachowania i ochrony przed kradzieżą występuje przy udostępnianiu tych druków w formie znacznie ostrzejszej niż przy drukach nowych. Ochronie stanu zachowania starych druków służą ograniczenia w udostępnianiu i wskazówki dotyczące obchodzenia się z książkami. Stare druki są udostępniane prezencyjnie, tzn. można $z$ nich korzystać tylko na miejscu, w samej bibliotece w przeznaczonym do tego celu pomieszczeniu nazwanym czytelnią. Nie każdy może korzystać ze starych druków. W zasadzie udostępnia się je pracownikom naukowym, zaś wszyscy inni muszą udowodnić potrzebę korzystania $z$ tych zabytkowych zbiorów oraz umiejętność obchodzenia się z nimi. Warunki korzystania tej kategorii czytelników ze zbiorów specjalnych ustalają regulaminy udostępniania, które zapewnić mają bezpieczeństwo udostępnianym książkom. Regulaminy czytelń udostępniających te zabytkowe zbiory pouczają czytelników, aby korzystając ze starych druków, nie narazili ich na uszkodzenia. Dodatkowym ograniczeniom w udostępnianiu podlegają druki rzadkie i cenne, są one udostępniane tylko w uzasadnionych przypadkach za zgodą kierownika oddziału.

$\mathrm{Z}$ zagadnieniem ochrony stanu zachowania starych druków wiążą się też inne zakresy techniki i praktyki bibliotecznej jak konserwacja i mikrofilmowanie. Dbałość o ochronę ich stanu zachowania wyraża się w szczególnie troskliwie prowadzonej konserwacji tych zbiorów. Każda biblioteka posiadająca zbiory specjalne powinna mieć także pracownię konserwacji nastawioną na restaurację zabytkowych zbiorów. Sprawy konserwacji łączą się z udostępnianiem o tyle, że bibliotekarz, przez którego ręce przechodzą udostępniane w czytelni stare druki, może najszybciej i najłatwiej stwierdzić ich uszkodzenia oraz potrzebę konserwacji. Bibliotekarz może bezpośrednio z czytelni skierować stare druki do pracowni konserwatorskiej w celu przeprowadzenia tzw. małej konserwacji, np. podklejenia kart, reperacji opraw. W pewnych przypadkach, jeśli uszkodzenia są poważniejsze, wymagające większych napraw, bibliotekarz może zarejestrować ksiąze do gruntownej konserwacji, którą prze- 
prowadzi się w późniejszym terminie, w zależności od możliwości pracowni konserwatorskiej.

Ochrona starych druków przed kradzieżą jest ogromnie ważna nie tylko ze względu na ich wysoką wartość materialną, ale także $\mathrm{z}$ powodu niemożliwości odkupienia utraconego druku. Strata starego druku jest więc nieporównywalnie większa od straty książki nowej. Aby zapobiec kradzieżom w czytelniach stosuje się przy udostępnianiu tych zbiorów szczególne środki ostrożności. Jednym $z$ ważniejszych jest prowadzenie własnego rejestru czytelników. Bibliotekarz dyżurujący w czytelni wpisuje każdego nowego czytelnika do specjalnego rejestru. Wpisu dokonuje się na podstawie legitymacji służbowej lub dowodu osobistego zawierającego personalia czytelnika, adres i zajmowane stanowisko w instytucji, w której jest zatrudniony. Pozwala to, w przypadku kradzieży starego druku, na identyfikację osób, które z niego korzystały.

Innym środkiem kontroli jest ewidencja ruchu książek, która umożliwia odtworzenie wstecz użytkownika poszczególnych dzieł, dzięki czemu nie trzeba zachowywać rewersów. Ewidencja ruchu książek pozwala także na kontrolowanie pracy magazyniera i zauważanie jego ewentualnych pomyłek przy włączaniu. Umożliwia ona sprawdzenie, oczywiście tylko wówczas jeśli jest prowadzona starannie, czy książka użytkowana w czytelni powróciła na swoje właściwe miejsce $\mathrm{w}$ magazynie, eliminuje więc w jakimś stopniu zagubienia własne biblioteki.

Niezmiernie ważna jest także kontrola egzemplarzy wydawanych dla czytelnika $z$ magazynu do czytelni. Trzeba jednak powiedzieć, że kontrola taka jest dość ograniczona, nie można bowiem kontrolować stanu zachowania całego egzemplarza za każdym razem, kiedy czytelnik zwraca wykorzystywany druk. Jest to szczególnie kłopotliwe i trudne do wykonania w przypadku klocków, atlasów i dzieł ilustrowanych. Np. sprawdzenie albumu zawierającego ok. 100 grafik jest ogromnie pracochłonne dla bibliotekarza oraz nieprzyjemne dla czytelnika, w obecności którego przeprowadza on kontrolę. Ponadto powodowałoby to dodatkowe zatrzymywanie czytelnika. Dodajmy, ze wielokrotne sprawdzanie egzemplarza karta po karcie nie jest obojętne dla jego stanu zachowania, tym bardziej, że czytelnik ogląda tylko niektóre grafiki czy mapy, bibliotekarz zaś byłby zmuszony przejrzeć wszystkie. Klocki podatne są na kradzieże przez to, że zawierają dużą ilość drobnych druczków, czasem bardzo cennych, co stwarza możliwość wyrywania ich w sposób, który nie pozostawia widocznych śladów; kradzież jest więc trudna 
do wykrycia, jeśli dokładnie nie sprawdza się klocków przed wydaniem ich czytelnikowi i po zwrocie. Możliwość takiego dokładnego sprawdzenia jest jednak ograniczona. ${ }^{35}$ Jeśli chodzi o sztychy, to trzeba podkreślić, że samodzielną wartość maja portrety, widoki miast $i$ architektury i te są często wyrywane. Bardzo pożądana jest ewidencja map i sztychów w poszczególnych egzemplarzach, zwłaszcza, że często nie posiadają one kompletu tych ilustracji. Dokładne dane dotyczące liczby sztychów, tablic, planów rozkładanych itd. i ich miejsce w książce (strony) powinny być naniesione na wewnętrzną stronę okładki. Oczywiście jest to łatwiejsze do przeprowadzenia w mniejszych, pod względem zasobów, oddziałach starych druków. W przypadku zbiorów dużych pierwszeństwo takiej ewidencji należy się wydaniom cenniejszym. Dopóki brakuje dokładnej ewidencji, ścisła kontrola map i ilustracji przed wydaniem i przy odbiorze egzemplarzy od czytelnika, praktycznie możliwa jest tylko w ograniczonym zakresie. Stąd decydującym czynnikiem, chroniącym przed kradzieżą stare druki udostępniane w czytelni, jest nadzór. Jest to szczególnie ważne w przypadku udostępniania druków rzadkich i cennych. Świadomość, że udostępnia się druk cenny, działa mobilizująco na bibliotekarza. Konieczne jest, żeby bibliotekarz znał wartość książek w swoim księgozbiorze nie gorzej niż potencjalny złodziej. Tu wyłania się problem ewidencji druków rzadkich i cennych.

W większości bibliotek bowiem cymelia nie są zewidencjonowane, stąd przy udostępnianiu wszystkie druki traktowane są tak samo. Spróbujmy zastanowić się jak praktycznie przeprowadzić taką ewidencję. Godne polecenia jako pomoc przy ustalaniu rzadkości druku lub jego wysokiej wartości sa bibliografie specjalistyczne, np. bibliofilskie jak J.Ch. Brunet: Manuel du libraire et de l'amateur des livres, Paris 18601865, T. 1-6 czy J.G.T. Graesse: Trésor de livres rares et précieux ou Nouveau dictionnaire bibliographique, Dresden 1859-1869, T. 1-8. Innym środkiem pomocniczym wskazującym obiekty o wysokiej wartości rynkowej są katalogi aukcyjne i antykwaryczne firm, które specjalizują się w handlu wartościowymi dziełami. Niezmiernie pomocne przy wyszukiwaniu książek o wysokiej wartości rynkowej są także wydawnictwa periodyczne rejestrujące ceny książek (zarówno księgarskie jak i aukcyjne) np. Jahrbuch der Auktionspreise fiur Bücher, Handschrifien und Autographen. Ergebnisse der Auktionem in Deutschland, Holland, Österreich

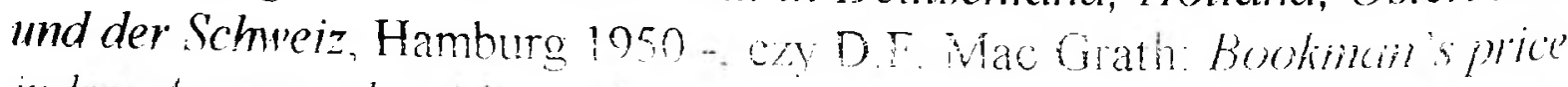

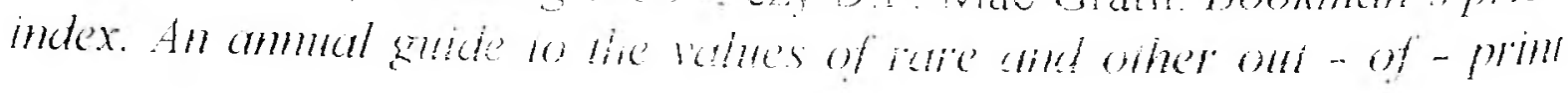


books and sets of periodicals, Detroit 1964 -. Dobrym środkiem służącym wyszukiwaniu wartościowych egzemplarzy w księgozbiorze jest wykorzystanie zamówień do wypożyczalni międzybibliotecznej, z których wynika, że poszukiwanej książki nie posiadają inne biblioteki. Również kwerendy wpływające do oddziałów starych druków można wykorzystać jako pomoc przy ustalaniu rzadkości lub wysokiej wartości druku. Nie wymaga to żadnych dodatkowych prac, po prostu bibliotekarz odpowiadający na kwerendy wychwytuje z korespondencji informacje mówiące o rzadkim występowaniu danego druku w innych bibliotekach polskich czy zagranicznych. Na tej samej zasadzie wykorzystać można wnioski o wydanie eksponatów na wystawy, które $z$ reguły dotyczą szczególnie charakterystycznych, wartościowych lub rzadkich dzieł. Godnym polecenia przy ustalaniu rzadkości druku jest też wykorzystanie wskazówek użytkowników znających problem rzadkiej książki.

Ogromną rolę odgrywa także mikrofilmowanie cymeliów, gdyż w razie zniszczenia egzemplarza, mikrofilm zachowuje jego tekst dla przyszłych pokolen. Ogólnokrajową akcję mikrofilmowania zbiorów prowadzi Biblioteka Narodowa. Niezależnie od Biblioteki Narodowej poszczególne biblioteki naukowe we własnym zakresie zabezpieczają swoje najcenniejsze druki przez zmikrofilmowanie. Negatywy mikrofilmów służą wyłącznie do wykonywania z nich kopii pozytywowych i powiększeń fotograficznych na zamówienie czytelnika, pozytywy natomiast udostępniane są $\mathrm{w}$ czytelni bądź wypożyczane międzybibliotecznie w kraju lub za granicę. Jednakże mikrofilmu nie robi się po to, żeby wyeliminować druk z obiegu. Użyteczność mikrofilmu jako środka zastępującego oryginat starego druku jest ograniczona, przede wszystkim ze względu na uciążliwość w korzystaniu. Oczywiście w przypadku rzeczy najcenniejszych pożądane jest udostępnianie w zastępstwie mikrofilmów, lub lepiej jeszcze fotokopii, jeśli biblioteka takowe posiada; są one łatwiejsze do odczytania. Ponadto pozytyw mikrofilmu jest niezwykle użyteczny w wypożyczaniu międzybibliotecznym. Przesyłanie bowiem starego druku pocztą wiąże się ze szczególnym ryzykiem nie tylko jego uszkodzenia, ale nawet zaginięcia. Stąd, lepszym rozwiązaniem jest wypożyczanie międzybiblioteczne mikrofilmu starego druku, szczególnie ważne jest to w przypadku unikatów, w wypożyczaniu których jak największa ostrożność jest całkowicie uzasadniona. Nie możemy jednake nie wspomniec o akcie shiząe do reprodukowania sprzęt, fakim prawie bez wyjątu, aysnonia polskie biblioteki takze przyczynia 
się do niszczenia egzemplarzy, z których wykonuje się mikrofilmy czy fotokopie. Należałoby zakupić za granica nowoczesne kamery pryzmatyczne pozwalajace fotografować jednocześnie dwie strony ksiazżi otwarte pod katem $60^{\circ}$. Tradycyjne kamery fotografuja pod katem $180^{\circ}$ lub $90^{\circ}$.

Czynności związane $z$ udostępnianiem zbiorów są nie mniej ważne niż prace związane z gromadzeniem, opracowywaniem i przechowywaniem zbiorów. Należałoby raczej powiedzieć, że całokształt działalności bibliotecznej powinien być podporządkowany udostępnianiu jako ostatecznemu celowi. Podstawowym aktem prawnym w zakresie bibliotek jest Ustawa o bibliotekach z dnia 9 kwietria $1968 \mathrm{r}$. W myśl art. 4.1. punkt 3 tej Ustawy zadaniem bibliotek jest m.in. „,udostępnianie materiałów bibliotecznych, udzielanie pomocy fachowej w ich wykorzystaniu oraz informowanie o zawartości zbiorów" ${ }^{36} \mathrm{~W}$ przypadku starych druków, które są zbiorami muzealnymi, ważnym przepisem prawnym jest także Ustawa o ochronie dóbr kultury i muzeach z dnia 15 lutego $1962 \mathrm{r}$. Artykuł 3 tej Ustawy w punkcie 1 mówi: „Ochrona dóbr kultury polega na zabezpieczeniu ich przed zniszczeniem, uszkodzeniem, dewastacja, zaginięciem lub wywozem za granice, na zapewnieniu im warunków trwalego zachowania, na opracowaniu dokumentacji naukowej, ewidencji i rejestracji oraz na ich konserwacji, restauracji, lub odhudowie, opartych na zasadach naukowych" ${ }^{37} \mathrm{~W}$ dalszej części tej Ustawy w art. $5 \mathrm{w}$ pkt. 9 wymienia się materiały biblioteczne będące przedmiotem ochrony. ${ }^{38}$ Są to m.in.: rękopisy, autografy, iluminacje, stare druki, pierwodruki, druki-unikaty i inne cymelia, oprawy. Zabytkowy charakter zbiorów starych druków powoduje ograniczenie ich udostępniania. Wspominaliśmy już, że są one udostępniane prezencyjne.

Organizacja pracy w czytelniach regulowana jest specjalnymi przepisami określającymi prawa i obowiazki użytkowników wobec biblioteki oraz zakres usług świadczonych użytkownikom przez bibliotekę. Stąd, obowiazkiem kierownictwa każdej biblioteki jest opracowanie i wprowadzenie w życie regulaminu wewnętrznego. ${ }^{39}$ Pożądane są odrębne regulaminy udostępniania starych druków tam, gdzie istnieja, także odrębne czytelnie tych zbiorów. Dobrze opracowany regulamin winien określać komu przysługuje prawo korzystania ze zbiorów starych druków oraz informować o sposobach i formach korzystania $z$ tych zbiorów. Powinien także dokładnie podawać godziny otwarcia czytelni oraz możliwości wykonywania reprodukcji ze starych druków. Musi on także szczególnie podkreślać cenność starego druku jako książki zabytkowej 
i tym samym wyraźnie określać odpowiedzialność czytelnika za użytkowane w czytelni stare druki. Regulamin czytelni starych druków zawiera także, jako podstawowe, przepisy dotyczace zachowania ciszy i nieprzeszkadzania w pracy innym użytkownikom. Należy dażyć do jak najkrótszych i jasnych sformułowań, regulamin nie powinien być obszerny. Tak opracowany i zatwierdzony przez kierownictwo biblioteki lub instytucji, przy której biblioteka działa, regulamin czytelni starych druków należy powielić $\mathrm{i}$ umieścić $\mathrm{w}$ widocznym i dostępnym miejscu czytelni. Dobrym rozwiązaniem jest przygotowanie regulaminu w formie ulotki.

Warto zapoznać się $\mathrm{z}$ organizacją udostępniania starych druków w Polsce na przykładzie wybranych bibliotek naukowych. Autorka wybrała 16 bibliotek - największych pod względem zasobów starych druków, w których przeprowadziła ankietę $\mathrm{z}$ zakresu udostępniania tej części zbiorów specjalnych. Dwie biblioteki spośród szesnastu, tj.: Biblioteka Uniwersytecka w Łodzi i Biblioteka Śląska w Katowicach nie odpowiedziały na ankietę. Autorka umieściła je więc w wykazie bibliotek o największych zasobach starych druków, ale nie uwzględniła ich, z powodu braku danych, w rozważaniach o formach udostępniania starych druków. Wykaz bibliotek przedstawia je według ilości posiadanych starych druków w woluminach w $1978 \mathrm{r}$.

1. Biblioteka Uniwersytecka, Wrocław $\quad-227621$

2. Biblioteka Narodowa

$-146389$

3. Biblioteka Uniwersytecka, Warszawa $\quad-120975$

4. Biblioteka Jagiellońska $\quad-112000$

5. Biblioteka Uniwersytecka, Poznań - 90000

6. Biblioteka Zakładu Narodowego im. Ossolińskich $\quad-75728$

7. Biblioteka Gdańska PAN

- 63053

8. Biblioteka Czartoryskich w Muzeum Narodowym, Kraków - 54900

9. Biblioteka Katolickiego Uniwersytetu Lubelskiego — 50455

10. Biblioteka Uniwersytecka, Toruń - 46694

11. Biblioteka Kórnicka PAN $\quad-39104$

12. Wojewódzka i Miejska Biblioteka Publiczna, Szczecin - 29000

13. Biblioteka Uniwersytecka, Łódź $\quad-28500$

14.Książnica Miejska, Toruń $\quad-26862$

15.Biblioteka Śląska $\quad-26000$

16. Biblioteka Czapskich w Muzeum Narodowym, Kraków - 22567 
W ankiecie autorka zadała następujące pytania:

1. Czy istnieje osobna czytelnia starych druków, czy też udostępnia się stare druki razem $z$ innymi zbiorami specjalnymi, jeśli tak, to $z$ jakimi,

2. Ile jest miejsc w czytelni starych druków (bądź też w czytelni zbiorów specjalnych),

3. Czy istnieje oddzielny regulamin udostępniania starych druków (bądź też zbiorów specjalnych), czy tylko ogólny regulamin udostępniania zbiorów,

4. Czy zostały wyodrębnione druki rzadkie tzw. cimelia (czy cimelia są przechowywane w oddzielnym magazynie),

5. Czy praktykuje się szczególne formy udostępniania cimeliów,

6. Czy zbiory sa mikrofilmowane w celu ich zabezpieczenia (jeśli tak, to ile posiadacie państwo mikrofilmów),

7. Jak wyglądało udostępnianie starych druków (lub jeśli nie ma takich danych, zbiorów specjalnych w ogólności) w roku 1978,

a) Ilu było odwiedzających,

b) Ile udostępniono dzieł w ilu woluminach,

c) Ile dzieł wypożyczono międzybibliotecznie $w$ kraju a ile za granicą (w tym ile mikrofilmów),

d) Czy udostępnia się stare druki zwiedzającym (wycieczkom i pojedynczym osobom), jeśli tak to w jakiej formie (doraźne wystawki, oprowadzanie w magazynach ewentualnie w inny sposób),

e) Czy urządza się wystawy starych druków, jak często.

$\mathrm{Na}$ pytania od 1 do 5 biblioteki udzieliły precyzyjnych odpowiedzi. Przy pytaniu 6 spośród dziewięciu bibliotek mikrofilmujących swoje zbiory cztery nie podały ilości posiadanych mikrofilmów. Generalnie wszystkie biblioteki mają niewielką ilość zmikrofilmowanych druków w stosun$\mathrm{ku}$ do posiadanych zbiorów. W większości bibliotek mikrofilmowanie nie jest akcją planowa. Na podstawie przeprowadzonej ankiety wyodrębniono kilka typów udostępniania starych druków w bibliotekach polskich:

1. udostępnianie starych druków w samodzielnych czytelniach,

2. udostępnianie starych druków wspólnie $z$ innymi zbiorami specjalnymi ( $\mathrm{z}$ jednym rodzajem lub kilkoma),

3. udostępnianie mieszane tzn. starych druków wspólnie $z$ innymi zbiorami, nie tylko specjalnymi, w czytelni ogólnej

Do pierwszej grupy należą: Biblioteka Uniwersytecka we Wrocławiu [dalej BUWr], Biblioteka Uniwersytecka warszawie, Biblioteka Jagiellonska, Biblioteka Uniwersytecka in Poznaniu. Biblioteka Zakladu Naro- 
dowego im. Ossolińskich, Biblioteka Katolickiego Uniwersytetu Lubelskiego - posiadające co najmniej 50 tys. woluminów. Rozwiązania organizacyjne przyjęte przez te książnice $w$ udostępnianiu starych druków przedstawiają się następująco. Biblioteka Uniwersytecka we Wrocławiu jest autorce najlepiej znana i z tych względów organizacja i problemy udostępniania $w$ tej Bibliotece analizowane są bardzo szeroko przy wykorzystaniu własnych doświadczeń zdobytych $w$ trakcie 7-letniego okresu pracy w Oddziale Starych Druków. Wrocławska Biblioteka Uniwersytecka pod względem ilości starych druków zajmuje pierwsze miejsce w kraju. Posiada na dzień 31 grudnia 1993 roku 229541 woluminów starych druków, 311069 dziel, w tym 3270 inkunabułów. Wśród tej ilości starych druków ok. 10000 to polonica, w tym 2190 polonica XVI w., zaś druków w języku polskim w ogóle jest około 1000 . Proporcjonalnie do ilości całego zbioru, liczba poloniców nie jest duża, ale w skali krajowej mają one znaczenie, niektóre $z$ nich są szczególnie rzadkie w Polsce.

Kolekcja Biblioteki Uniwersyteckiej składa się z kilku zespołów zbiorów, m.in.:

1. byłej wrocławskiej Biblioteki Miejskiej,

2. byłej wrocławskiej Biblioteki Uniwersyteckiej,

3. dawnej Biblioteki Gimnazjum Brzeskiego,

4. Biblioteki jednego $z$ ostatnich Piastów Śląskich, księcia legnickiego Jerzego Rudolfa, tzw. Rudolphina,

5. Biblioteki Kościoła św. Piotra i Pawła w Legnicy

oraz szeregu śląskich bibliotek prowincjonalnych zarówno szkolnych, pałacowych jak i prywatnych.

Inkunabuły reprezentują przede wszystkim tłocznie niemieckiego obszaru językowego, wiele jest także inkunabułów włoskich, francuskich i niderlandzkich. Te duże i bogate zbiory starych druków udostępniane sa w czytelni liczącej 6 miejsc, od poniedziałku do piątku w godz. $8^{00}-15^{00}$. W godzinach popołudniowych i w soboty stare druki (z wyjątkiem inkunabułów i cymeliów przechowywanych w kasie pancernej) są udostępniane w Czytelni Zbiorów Specjalnych, oczywiście po uprzednim zamówieniu.

Sposoby i formy korzystania z wrocławskiej kolekcji określa Regulamin udostępniania starych druków opracowany na podstawie Zarządzenia Nr 3 Rektora Uniwersytetu Wrocławskiego z dnia 28 stycznia 1987 r. w sprawie ustalenia regulaminów udostępniania zbiorów specjalnych Biblioteki Uniwersyteckiej. Regulamin ten informuje czytelnika 
o formalnościach $\mathrm{z}$ jakimi spotyka się $\mathrm{w}$ czytelni. Regulamin przejrzyście określa warunki udostępniania zbiorów, z których moga korzystać pracownicy instytucji naukowych, kulturalnych i oświatowych oraz osoby zajmujące się samodzielną pracą naukową. Studenci mogą korzystać ze zbiorów po przedstawieniu pisma polecającego od opiekuna naukowego. Każdy czytelnik zgłaszający się po raz pierwszy do Czytelni starych druków zostaje wpisany do rejestru czytelników w sposób przedstawiony już wcześniej. Wszystkie książki, wydane z magazynu dla czytelnika na podstawie złożonego wcześniej zamówienia, są rejestrowane w ewidencji udostępniania w czytelni. Wydawane książki mają być kontrolowane zarówno przed wydaniem jak i po zwrocie. Z kolei czytelnik powinien sprawdzić zgodność otrzymanych książek $z$ zamówieniem, a wszelkie braki zgłosić natychmiast dyżurnemu bibliotekarzowi. Regulamin określa także ilość książek, które czytelnik może jednorazowo zamówić do czytelni (w BUWr - 5). Oczywiście nie jest to żaden rygor i nie oznacza konieczności ograniczania ilości udostępnianych dzieł. Jest to swoisty przywilej bibliotekarza, któremu wolno w okresie spiętrzenia prac czy z innych względów ograniczyć ilość woluminów udostępnianych czytelnikowi. Regulamin uczula czytelnika na właściwe obchodzenie się z książką zabytkową tak, by nie ucierpiał jej stan zachowania. Podkreśla także, że nie wykonuje się kserokopii ze starych druków, lecz tylko mikrofilmy i fotokopie. Kierownik Oddziału może odmówić wykonania reprodukcji, jeżeli fotografowanie mogłoby spowodować uszkodzenie książki w złym stanie zachowania. Regulamin ogranicza także wypożyczenia międzybiblioteczne naszych starych druków. I tak w wypożyczaniu międzybibliotecznym nie udostępnia się inkunabułów i druków cennych. Wypożyczenia tych druków stosowane wyjątkowo wymagają zgody Dyrekcji Biblioteki i przewożone są przez posłańców. W praktyce nie wypożycza się międzybibliotecznie oryginałów lecz kopie, najczęściej mikrofilmy. Na dzień 31 grudnia 1993 r. Oddział Starych Druków Biblioteki Uniwersyteckiej we Wrocławiu posiada 7000 jednostek inwentarzowych mikrofilmów. Oryginały wypożyczane są w wyjątkowych przypadkach do celów badawczych, głównie do Biblioteki Narodowej. Od bardzo dawna nie praktykuje się przesyłania starych druków pocztą, bez względu na częstotliwość ich występowania $w$ zbiorach. W tym punkcie Regulamin z 1987 r. wymaga wniesienia poprawki, gdyż zezwala on na przesyłanie mniej cennych druków pocztą. Propozycje zmian do regulaminu udostepniania starych druków zostaly zołoszone 
do Rady Bibliotecznej, która pracuje nad nowym regulaminem udostępniania zbiorów Biblioteki Uniwersyteckiej we Wrocławiu.

Przedstawiamy poniżej szczegółową statystykę udostępniania starych druków we Wrocławiu w 1987 i 1993 r.:

\begin{tabular}{|l|l|l|l|l|l|l|}
\hline Rok & $\begin{array}{l}\text { Liczba } \\
\text { odwiedzin }\end{array}$ & $\begin{array}{l}\text { Liczba udo- } \\
\text { stępnianych } \\
\text { dzieł w wol. }\end{array}$ & $\begin{array}{l}\text { Liczba wy- } \\
\text { pożyczeń } \\
\text { międzybibl. } \\
\text { dziel w wol. }\end{array}$ & $\begin{array}{l}\text { Liczba wypo- } \\
\text { zyczeń mię- } \\
\text { dzybibl. } \\
\text { mikrotilmów }\end{array}$ & $\begin{array}{l}\text { Grupy wy- } \\
\text { cieczkowe; } \\
\text { liczba osób }\end{array}$ & $\begin{array}{l}\text { Zagraniczni } \\
\text { goście od- } \\
\text { wiedzajacy } \\
\text { Bibliotekę } \\
\text { indywi- } \\
\text { dualnie }\end{array}$ \\
\hline 1987 & 711 & $\begin{array}{l}10077 \mathrm{dz} \\
\mathrm{w} \\
6424 \mathrm{wol}\end{array}$ & $\begin{array}{l}35 \mathrm{dz} . \\
\mathrm{w} \\
41 \mathrm{wol} .\end{array}$ & 6 & $38 ; 690$ & 43 \\
\hline 1993 & 892 & $\begin{array}{l}6972 \mathrm{dz} \\
\mathrm{w} \\
7321 \mathrm{wol} .\end{array}$ & $\begin{array}{l}47 \mathrm{dz} . \\
\mathrm{w} \\
47 \mathrm{wol} .\end{array}$ & 16 & $16 ; 259$ & 19 \\
\hline
\end{tabular}

Należy dodać, że w ostatnich latach nie były urządzane żadne wystawy okolicznościowe czy też tematyczne, stare druki biorą udział w ogólnych wystawach organizowanych przez BUWr razem z książkami nowymi. Wyjątek stanowi wystawka zbiorów specjalnych (m.in. starych druków) obrazująca wysiłki Biblioteki Uniwersyteckiej we Wrocławiu w zakresie restauracji i konserwacji zbiorów zorganizowana 9 czerwca 1988 r. dla uczestników III Konferencji Konserwatorów i Bibliotekarzy. Wystawka ta trwała tylko 1 dzień i szkoda, że obejrzało ją tylko tak szczupłe grono. Ponadto pojedyncze egzemplarze starych druków wypożyczane są do innych bibliotek i muzeów w kraju. Przykładowo w 1993 r. Biblioteka Uniwersytecka udostępniła eksponaty na wystawy do:

- Muzeum Miedzi w Legnicy na wystawę Legnica in ictu oculi

- Muzeum Historycznego we Wrocławiu na wystawę Mauzolea Piastowskie

- Muzeum Okręgowego w Toruniu na wystawę Kopernik - życie i dzielo

- Muzeum Archeologicznego we Wrocławiu na uroczystość otwarcia wystawy Ameryka - spotkanie dwóch światów - list Krzysztofa Kolumba z 1493 r. o odkryciu Ameryki.

Organizacja udostępniania starych druków w pozostałych bibliotekach musi być ograniczona do zagadnień podstawowych. Autorka przedstawia więc analogie i różnice wyszczególnione przez ankietowane biblioteki. W grupie bibliotek udostępniających stare druki w samodzielnych czytelniach aż cztery spośród nich posiada także oddzielny regulamin udostęp- 
niania tych zbiorów. Jedynie Biblioteka Jagiellońska i Biblioteka KUL korzystają z ogólnego regulaminu udostępniania. Warto dodać, że w Bibliotece Jagiellońskiej, druki najcenniejsze, tj. inkunabuły i cymelia mają metryczki, w których korzystający z nich czytelnicy wpisują swoje dane personalne, a także temat i cel pracy. Studenci muszą przedstawić pismo polecające od promotora pracy seminaryjnej lub magisterskiej.

Oddzielne regulaminy udostępniania starych druków w Bibliotece Uniwersyteckiej w Warszawie, Bibliotece Uniwersyteckiej w Poznaniu oraz Bibliotece Ossolineum omawiaja szczegółowo kto i w jaki sposób może korzystać $\mathrm{z}$ tych zbiorów. $\mathrm{Z}$ reguły prawo korzystania $\mathrm{z}$ czytelni i zbiorów starych druków posiadaja pracownicy naukowi i studenci (za poświadczeniem promotora). W Bibliotece Uniwersyteckiej w Warszawie umożliwia się korzystanie ze starych druków w celach naukowych, dydaktycznych, twórczości artystycznej itp. także innym czytelnikom na podstawie karty bibliotecznej tej Biblioteki, legitymacji służbowej, studenckiej lub dowodu osobistego. Bardziej zamkniętą biblioteka, jeśli chodzi o udostępnianie starych druków, jest Ossolineum we Wrocławiu, gdzie czytelnicy spoza wymienionych wyżej grup moga korzystać tylko po uzyskaniu zgody Dyrekcji. Zarówno w Bibliotece Uniwersyteckiej w Warszawie jak i Bibliotece Ossolineum korzystający w czytelni po raz pierwszy obowiązany jest wypełnić deklarację czytelnika (w BUWr zamiast tego prowadzi się wspomniany już rejestr czytelników). W grupie bibliotek udostępniających stare druki w samodzielnych czytelniach nie praktykuje się szczególnych form udostępniania cymeliów. Jest to zrozumiałe, ponieważ w księgozbiorach tych, za wyjątkiem Biblioteki Jagiellońskiej, nie ma jak dotąd, ewidencji druków rzadkich, o czym powiedziano wyżej. Jedynie Biblioteka Uniwersytecka w Warszawie, przechowująca niewielką ilość cymeliów w szafie pancernej, udostępnia je wyłącznie za zgodą kierownika oddziału. Mimo braku ewidencji cymeliów trzy biblioteki $\mathrm{z}$ tej grupy, a mianowicie Biblioteka Uniwersytecka w Warszawie, Biblioteka Uniwersytecka w Poznaniu oraz Ossolineum mikrofilmują cenniejsze stare druki w celu ich zabezpieczenia. Mikrofilmy te sa gromadzone i przechowywane w Oddziałach Mikroform, natomiast udostępnia się je w czytelni starych druków albo czytelni mikrofilmów lub też $\mathrm{w}$ czytelni ogólnej. Warto dodać, że biblioteki te, podobnie jak Biblioteka Uniwersytecka we Wrocławiu, objęte są ogólnokrajową akcja mikrofilmowania zbiorów, prowadzoną przez Zakład Zbiorów Mikrofilmowych Biblioteki Narodowej, stąd prze- 
chowuja one mikrofilmy wykonane u siebie oraz pozytywy mikrofilmowe swoich druków wykonane przez Bibliotekę Narodową. I tak Ossolineum było jedną z pierwszych bibliotek, które objęto tą akcją przy czym dążono przede wszystkim do zmikrofilmowania wszystkich rękopisów, a w mniejszym wymiarze starych druków. Dla przykładu w 1987 r. Biblioteka Uniwersytecka w Warszawie miała zmikrofilmowanych 907 pozycji, zaś Biblioteka Uniwersytecka w Poznaniu około 300.

Udostępnianie starych druków wspólnie $\mathrm{z}$ innymi zbiorami specjalnymi odbywa się w trzech bibliotekach: Bibliotece Narodowej, Bibliotece Uniwersyteckiej w Toruniu i Miejskiej Bibliotece Publicznej w Szczecinie. Biblioteka Narodowa zgodnie ze swoją strukturą i regulaminami, udostępnia stare druki wraz $z$ rękopisami i muzykaliami w Czytelni Zbiorów Specjalnych. W godzinach popołudniowych udostępnia się w tej czytelni także zbiory ikonograficzne i kartograficzne, wcześniej zamówione. Natomiast pozostałe dwie biblioteki mają wspólną czytelnię dla rękopisów i starych druków, przy czym zbiory te tworzą jeden wspólny oddział w Bibliotece Uniwersyteckiej w Toruniu, zaś w Wojewódzkiej i Miejskiej Bibliotece Publicznej w Szczecinie są one odrębne.

Regulamin Czytelni Zbiorów Specjalnych Biblioteki Narodowej, podobnie jak regulaminy czyteln starych druków $w$ innych bibliotekach, szczegółowo informuje kto i w jakiej formie może korzystać z czytelni. Regulamin ten podkreśla, że zbiory specjalne udostępnia się pracownikom naukowym, zaś wszelkie inne osoby muszą uzyskać zezwolenie kierownika zakładu, z którego zbiorów chcą korzystać. Osoby korzystające po raz pierwszy obowiązane są do wypełnienia deklaracji, natomiast dawni czytelnicy do aktualizacji danych. Również Wojewódzka i Miejska Biblioteka Publiczna w Szczecinie posiada ramowy regulamin udostępniania starych druków. Zgodnie z tym regulaminem prawo korzystania ze starych druków mają wszyscy obywatele od ukończonych 18 lat życia, bez względu na to czy są stałymi czytelnikami, czy też chcą korzystạ́ z czytelni doraźnie. Regulamin tej biblioteki podobnie jak wszystkie inne regulaminy udostępniania starych druków, uczula czytelnika, aby korzystając z tych zabytkowych zbiorów, nie narażał ich na uszkodzenie, np. nie używał książek jako podkładki, nie robił notatek na książkach; zabronione jest także kopiowanie ilustracji i map.

Biblioteki posługujące się odrębnymi regulaminami starych druków oraz Czytelnia Zbiorów Specjalnych Biblioteki Narodowej zastrzegają sobie prawo odmówienia czytelnikowi udostepnienia zamawianych dru- 
ków, np. ze względu na zły stan zachowania. Natomiast Biblioteka Uniwersytecka w Toruniu swoje obiekty cenne i rzadkie: inkunabuły, polonica XVI w., rękopisy średniowieczne pergaminowe i iluminowane przechowywane $w$ sejfach $w$ magazynie starych druków i rękopisów, udostępnia wyłącznie za wiedzą i zgodą dyrektora w szczególnie uzasadnionych przypadkach. Wszystkie te cymelia zostały zmikrofilmowane, mikrofilmy sa przechowywane i udostępniane w Oddziale Mikrofilmów. Obecnie mikrofilmuje się tylko druki na zamówienie czytelników, zwłaszcza zagranicznych, pozostawiając w swoich zbiorach negatyw. Zakład Starych Druków Biblioteki Narodowej mikrofilmuje przede wszystkim polonica i rzadkie druki obce, chociaż nie wyodrębnia się tam cymeliów. Nie prowadzi się akcji mikrofilmowania cymeliów w Wojewódzkiej i Miejskiej Bibliotece Publicznej w Szczecinie, chociaż 22 najcenniejsze stare druki są zmikrofilmowane i mogą być udostępniane w tej formie.

Przedstawiany trzeci typ udostępniania starych druków, nazwany został przez autorkę wcześniej, udostępnianiem mieszanym. Reprezentuje go pięć pozostałych bibliotek, które odpowiedziały na ankietę. Są to biblioteki Polskiej Akademii Nauk: Gdańska i Kórnicka, muzealne: Czartoryskich i Czapskich w Krakowie oraz Książnica Miejska w Toruniu. Udostępniają one stare druki wspólnie z innymi zbiorami, także z książkami nowymi w czytelni ogólnej. Czytelnia taka ma jednak charakter czytelni zbiorów specjalnych typu uniwersyteckiego, ponieważ całe zbiory tych bibliotek mają charakter prezencyjny. Biblioteki te posługuja się ogólnym regulaminem udostępniania, w którym są zwykle szczegółowe postanowienia dotyczące korzystania ze starych druków. I tak np. w Bibliotece Gdańskiej PAN korzystanie zarówno z rękopisów jak i starych druków uzależnione jest od zgody dyrekcji biblioteki. W celu uzyskania zgody konieczne jest wypełnienie „Arkusza czytelnika”, który wydaje i przyjmuje dyżurny bibliotekarz. Dla podkreślenia dodajmy, że zgoda dyrekcji obejmuje tylko materiały dotyczące tematu określonego w „Arkuszu czytelnika”. Osoby nie będące samodzielnymi pracownikami naukowo-badawczymi zobowiązane są dołączyć zaświadczenie osoby lub instytucji nadzorującej opracowanie tematu. Podobnie w Bibliotece Kórnickiej PAN wymagane jest takie zaświadczenie. Natomiast w Bibliotece Czartoryskich i Czapskich wymaga się poświadczenia promotora tylko w przypadku korzystania z rękopisów.

W trzech bibliotekach: Gdanskiej PAN, Czaitoryskich w Krakowie i Kórnickiej PAN wyodrębnione zostały cymelia. W dwu pierwszych cy- 
melia udostępnia się podobnie jak pozostałe stare druki. Natomiast regulamin udostępniania Biblioteki Kórnickiej wyłącza z udostępniania dzieła będące $\mathrm{w}$ złym stanie zachowania lub przedstawiające szczególną wartość, $w$ takich przypadkach udostępnia się jedynie mikrofilmy. Dodać należy, że w Bibliotece tej zmikrofilmowano już ponad 4000 jednostek inwentarzowych starych druków (dane z 1987 r.). Akcję mikrofilmowania najcenniejszych i jednocześnie najczęściej udostępnianych druków prowadzi także Biblioteka Gdańska PAN. Zbiory jej są również mikrofilmowane przez Bibliotekę Narodową. Z. grupy bibliotek o udostępnianiu mieszanym jedynie Książnica Miejska w Toruniu i Biblioteka Czapskich nie mikrofilmują swoich zbiorów dla zabezpieczenia, przy czym ta ostatnia planuje to robić $w$ przyszłości.

Dla lepszego zobrazowania problematyki udostępniania starych druków przedstawiamy w tabeli statystykę wypożyczeń starych druków w poszczególnych bibliotekach za rok 1987. W tabeli zachowujemy kolejność bibliotek według wielkości zasobów:

\begin{tabular}{|c|c|c|c|c|}
\hline L.p. & Nazwa biblioteki & $\begin{array}{l}\text { Liczba od- } \\
\text { wiedzin }\end{array}$ & $\begin{array}{l}\text { Liczba udo- } \\
\text { stępnianych } \\
\text { dziel, wol. }\end{array}$ & $\begin{array}{l}\text { Liczba dziel wypoży- } \\
\text { czonych międzybi- } \\
\text { bliot. }\end{array}$ \\
\hline 1. & $\begin{array}{l}\text { Bibl. Uniw.. Wro- } \\
\text { claw }\end{array}$ & 711 & $\begin{array}{r}10077 \mathrm{dz} \\
w 6+24 \mathrm{wol} \\
\end{array}$ & $\begin{array}{r}35 \mathrm{~d} z . \mathrm{w}+\mathrm{l} \text { wol. (w } \\
\operatorname{tym} 6 \mathrm{MF})\end{array}$ \\
\hline 2. & Bibl. Narodowa & $\begin{array}{l}\text { w Czyt. Zb. } \\
\text { Specjalnych } \\
3017\end{array}$ & $\begin{array}{r}994 \mathrm{dz} \\
\text { w1 } 191 \mathrm{wol}\end{array}$ & $\begin{array}{r}122 \mathrm{~d} z \\
w 170 \mathrm{wol} \\
+3568 \mathrm{MF} \\
\end{array}$ \\
\hline 3. & $\begin{array}{l}\text { Bibl. Uniw., } \\
\text { Warszawa } \\
\end{array}$ & 1286 & $3483 \mathrm{wol}$ & $85 \mathrm{wol}$. \\
\hline 4. & Bibl. Jagiellońska & 4194 & $5563 \mathrm{wol}$. & $69 \mathrm{dz}$ \\
\hline 5. & $\begin{array}{l}\text { Bibl. Uniw., } \\
\text { Poznań }\end{array}$ & 127 & $112 \mathrm{wol}$. & 11 \\
\hline 6. & Bibl. Ossolineum & 1216 & $\begin{array}{r}4555 \mathrm{dz} \\
\mathrm{w} 2892 \mathrm{wol} \\
\end{array}$ & $\begin{array}{r}152 \mathrm{~d} z . \\
w 147 \text { wol. } \\
\end{array}$ \\
\hline 7. & Bibl. Gdańska PAN & $\begin{array}{l}\text { brak doklad- } \\
\text { nych danỵch }\end{array}$ & $\begin{array}{r}810 \mathrm{dz} \\
\text { w } 1000 \mathrm{wol}\end{array}$ & $\begin{array}{r}32 \mathrm{dz} \\
\mathrm{w} 38 \mathrm{wol} \\
+9 \mathrm{MF} \\
\end{array}$ \\
\hline 8. & $\begin{array}{l}\text { Bibl. Czartoryskich. } \\
\text { Kraków } \\
\end{array}$ & \multicolumn{3}{|c|}{$\begin{array}{c}\text { Nie ma dokladnych danych dotyczaçch tylko starych } \\
\text { druków }\end{array}$} \\
\hline 9. & Bibl. KUL. Lublin & 726 & 1904 & 16 \\
\hline 10. & Bibl. Uniw., Toruń & 932 & $\begin{array}{r}786 \mathrm{dz} \\
\text { w } 1235 \mathrm{wol} . \\
\end{array}$ & $4+\mathrm{d} z$ \\
\hline 11. & Bibl. Kónnicka PAN & $\begin{array}{l}\text { brak doklad- } \\
\text { nych danych }\end{array}$ & $\begin{array}{r}5600 \text { jednostek } \\
\text { inwentar/owych } \\
\text { 2b. specjalnisch }\end{array}$ & $\begin{array}{l}55 \text { jedn inw. zb. spe- } \\
\text { cjalnych+6 } 6 \text { MF }\end{array}$ \\
\hline
\end{tabular}




\begin{tabular}{|c|c|c|c|c|}
\hline 12. & WiMBP,Szczecin & 154 & 233 wol. & 8 wol. $+11 \mathrm{MF}$ \\
\hline 13. & $\begin{array}{l}\text { Książnica Miejska, } \\
\text { Toruń }\end{array}$ & \multicolumn{3}{|c|}{$\begin{array}{l}\text { Nie ma dokladnych danych dotyczacych tylko starych } \\
\text { druków }\end{array}$} \\
\hline 14. & $\begin{array}{l}\text { Bibl. Czapskich, } \\
\text { Kraków }\end{array}$ & 65 & 57 & 12 \\
\hline
\end{tabular}

Trudno jednak porównywać liczby uzyskane w odpowiedzi na pytanie 7 ankiety i zawarte $w$ tabeli. Tylko pięć bibliotek spośród czternastu precyzyjnie podało ilość udostępnionych dzieł i woluminów starych druków, cztery biblioteki podały ilość udostępnionych woluminów, dwie biblioteki podały tylko liczbe nie precyzując, czy są to dzieła, czy woluminy. W trzech bibliotekach nie ma dokładnych danych dotyczących udostępniania starych druków. Są to: Biblioteka Kórnicka PAN, Biblioteka Czartoryskich i Książnica Miejska w Toruniu. Nie jest naszym zamierzeniem szczegółowa analiza liczb, ponieważ w przypadku starych druków nie może być mowy o masowym ich wykorzystaniu. Dodać należy, że dokładna statystyka jest możliwa tylko w przypadku bibliotek udostępniających stare druki w oddzielnej czytelni. Przy udostępnianiu wspólnym z innymi zbiorami specjalnymi, a jeszcze bardziej z książkami nowymi trudno ustalić ilu czytelników korzystało tylko ze starych druków, np. w Bibliotece Gdańskiej PAN, Czartoryskich w Krakowie, Czapskich czy też Czytelni Zbiorów Specjalnych w Bibliotece Narodowej.

Inną formą udostępniania starych druków jest wypożyczanie międzybiblioteczne krajowe i zagraniczne. Zasady wypożyczania międzybibliotecznego materiałów bibliotecznych, w tym także zbiorów specjalnych, przez biblioteki ogólnokrajowej sieci bibliotecznej określa Zarzqdzenie Ministra Kultury i Sztuki z dnia 25 czerwca 1980 r. (Monitor Polski nr 12, poz. 54). Zgodnie $z$ ustaleniami tego dokumentu $w$ punkcie 33, wszystkie przedstawione biblioteki wypożyczają międzybibliotecznie w kraju, większość tylko do bibliotek, które posiadają odrębne czytelnie zbiorów specjalnych, bądź też w szczególnych okolicznościach, np. na wystawy. W przypadku zbiorów szczególnie cennych biblioteka wypożyczająca zobowiązana jest do ubezpieczenia wypożyczanych materiałów (punkt 37 Zarządzenia). Większość bibliotek nie przesyła druków pocztą, lecz przez posłańców. Pocztą wysyła się tylko mikrofilmy. Stwierdzić należy, że wszystkie ankietowane biblioteki nie wypożyczają starych druków międzybibliotecznie za granicę, chociaż nie jest to zabronione ustawą. Jest to shuszne rozwiązanie, gdyż wypożyczać $w$ ten sposób można tylko takie materiały biblioteczne, które mogą byc odtworzone, odkupione Jest to tez zgodne $z$ punktem 4 wspomnianego 
Zarządzenia, który mówi, że: „Biblioteka może odmówić wypożyczania rzadkich i szczególnie cennych materiatów bibliotecznych" ${ }^{40}$ Zbiory specjalne, w tym także dzieła rzadkie, musza być przede wszystkim w swym nienaruszonym kształcie zachowane dla potomności. Szczególną rolę w tym zakresie spełnia Biblioteka Narodowa jako centralna biblioteka państwa, stąd od niedawna posiada ona bardzo szczegółowe przepisy dotyczące wypożyczania międzybibliotecznego. ${ }^{41}$

Zarządzenie dotyczące zasad wypożyczania zbiorów specjalnych Biblioteki Narodowej określa cztery kategorie zbiorów specjalnych, które powinny podlegać szczególnej ochronie i w konsekwencji być wyłączone w całości lub częściowo $\mathrm{z}$ wypożyczania poza obręb siedziby Biblioteki Narodowej. Są to:

- kategoria I - dokumenty szczególnie chronione - cimelia,

- kategoria II - dokumenty szczególnie chronione,

- kategoria III - pozostałe zbiory specjalne (nie będące dokumentami szczególnie chronionymi),

- kategoria IV - zbiory mikroform.

Stare druki moga się znaleźć w każdej z tych grup, gdyż do kategorii I zalicza się unikalne dokumenty biblioteczne o szczególnej wartości zabytkowej dla kultury narodowej lub ogólnoludzkiej; do grupy II - dokumenty o dużej wartości zabytkowej znajdujące się w zbiorach Biblioteki Narodowej $\mathrm{w}$ pojedynczych egzemplarzach, egzemplarze posiadające zabytkowe oprawy, egzemplarze o cennych proweniencjach lub innych specjalnych cechach wydawniczych lub bibliotecznych, ponadto woluminy zawierające dużą ilość współoprawnych starych druków (tzw. klocki introligatorskie), obiekty $\mathrm{w}$ złym stanie zachowania, $\mathrm{z}$ uszkodzeniami; do grupy III - m.in. inkunabuły, druki XVI wieku, pojedyncze egzemplarze poloników XVII-XVIII wieku oraz cenne druki obce; do grupy IV mikrofilmy - negatywy, egzemplarze archiwalne pozytywów.

Wypożyczanie tych kategorii dokumentów wymaga: dla grupy I - pisemnej zgody dyrektora Biblioteki Narodowej (konieczna jest opinia kierownika Pracowni Konserwacji Książki a o każdym wypożyczaniu informuje się Ministerstwo Kultury i Sztuki); dla grupy II - pozytywnej opinii kierownika Działu Zbiorów Specjalnych zatwierdzonej przez dyrektora Bibliotek Narodowej; w przypadku grupy III - zgody kierownika Działu Zbiorów Specjalnych (pozostałe druki wypożycza się za zgodą kierownika Zakładu Starych Druków); w przypadku grupy IV - zgody kierownika 
Zakładu Zbiorów Mikrofilmowych na wypożyczenie pozytywów (negatywów nie wypożycza się w ogóle).

Wszystkie ankietowane biblioteki w węższym lub szerszym zakresie organizuja pokazy starych druków, doraźne wystawki czy też wystawy tematyczne. Większosśc bibliotek uniwersyteckich i bibliotek PAN organizuje pokazy z prelekcjami dla studentów bibliotekoznawstwa, studentów innych wydziałów humanistycznych, bibliotekarzy, a w przypadku bibliotek uniwersyteckich, bardzo często także dla gości uniwersytetów. Warto dodać, że tylko niektóre z bibliotek, jak np. Biblioteka Uniwersytecka w Toruniu czy Biblioteka Gdańska PAN wprowadzają gości do magazynu, przy czym postępuje się tak tylko w przypadku specjalistów, osób szczególnie zainteresowanych przechowywaniem starych druków, np. dyrektorów bibliotek w kraju i za granica, pracowników starych druków w innych bibliotekach. Inaczej rozwiązuje problem wycieczek Biblioteka Kórnicka PAN, która ma stałą ekspozycję starych druków w postaci makiet dla zwiedzających Muzeum Kórnickie. Od czasu do czasu Biblioteka ta organizuje także wystawki specjalistyczne. Natomiast biblioteki publiczne: Wojewódzka i Miejska Biblioteka Publiczna w Szczecinie oraz Książnica Miejska w Toruniu praktykuja pokazywanie starych druków głównie na lekcjach bibliotecznych dla uczniów.

Wszystkie biblioteki organizują także wystawy, przy czym bardzo rzadko prezentuja one tylko zasoby starych druków. Przykładem wystaw samodzielnych są organizowane przez Bibliotekę Uniwersytecką w Warszawie, np. w 1978 r. Sztuka typograficzna dawnej Warszawy, w 1979 r. Druki socynianskie w zbiorach BUW, w 1983 r. Sobiesciana w zbiorach $B U W$.

Najczęściej stare druki biorą udział w wystawach ogólnych biblioteki, np. wystawa Miasta wloskie zorganizowana w 1986 r. przez Bibliotekę Uniwersytecka w Poznaniu; Polska Jagiellonów 1386-1572 zorganizowana przez Bibliotekę Jagiellońską w Zamku Królewskim w Warszawie czy wreszcie Skarby kultury narodowej Ossolineum, która to wystawa odbyła się w 1987 r. w Białymstoku. Szerszą działalność wystawiennicza prowadzi także Biblioteka Narodowa. Biblioteka ta przygotowuje wystawy najczęściej z okazji znaczących wydarzeń w dziejach kultury polskiej, np. 200-lecia Konstytucji 3 Maja, 60-lecia Biblioteki Narodowej. Tego typu wystawy tematyczne są udostępniane szerszym kręgom społeczeństwa. Dodać należy, że przygotowanie wystawy tematycznej pochlania wiele godzin, stąd też znikoma jest ich ilość w bibliotekach. Pojedyn- 
cze egzemplarze starych druków biblioteki wypożyczają bez większych ograniczeń na wystawy do innych bibliotek i muzeów w kraju.

Reasumując dotychczasowe rozważania, podkreślić raz jeszcze należy potrzebę oddzielnych regulaminów udostępniania starych druków tam, gdzie jest oddzielne ich udostępnianie. Ograniczenie czytelnika regulaminem czytelni, a także zobowiązanie go do rozmaitego rodzaju form rejestrowania swojej obecności, posiada duży sens i walory wychowawcze. Niezbędne staje się także ograniczenie korzystania $\mathrm{z}$ cymeliów w oddziałach starych druków. Głównym i najważniejszym zadaniem jest zabezpieczenie i ochrona zbiorów rzadkich i w związku z tym tzw. powszechna dostępność publikacji nie może być w przypadku tych zbiorów przestrzegana.

\section{Wnioski końcowe}

Głównym problemem w udostępnianiu starych druków jest zabezpieczenie ich przed kradzieżą i zniszczeniem. Sumując krótko nasze rozważania, trzeba uznać, że do ważnych środków ochrony starych druków przed kradzieżą w czytelniach powinny należeć ewidencja cymeliów, rejestr czytelników i ewidencja ruchu książek między magazynem i czytelnią a przede wszystkim fachowy nadzór nad czytelnią ze zwróceniem szczególnej uwagi na druki bardziej od innych na kradzieże podatne. Stwierdziliśmy, że ankietowane biblioteki (bez względu na typ udostępniania) obwarowały udostępnianie tych zbiorów odpowiednimi regulaminami i zachowują wszelkie możliwe środki bezpieczeństwa. Niezwykle ważne jest ścisłe przestrzeganie regulaminu udostępniania zarówno przez dyżurnego bibliotekarza jak i czytelnika odnośnie kontroli stanu zachowania udostępnianych druków. Druki muszą być kontrolowane zarówno przed wydaniem jak i po zwrocie przez bibliotekarza. Czytelnik także sprawdza zgodność otrzymanych druków z zamówieniem. Bibliotekarz czuwa także nad właściwym korzystaniem czytelnika z książki zabytkowej, tak aby nie ucierpiał jej stan zachowania. Trzeba przyznać, że jedyną skuteczną metodą, w tym względzie, jest stały, zwiększony nadzór w czytelni.

W niniejszym opracowaniu przewija się równolegle, ściśle złączony $z$ udostępnianiem starych druków, temat: problematyka druków rzadkich i cennych. Poświęcono mu dużo miejsca, ponieważ szczególnie ważna 
jest, w naszym przekonaniu, ochrona stanu zachowania cymeliów, do tej pory zaś w Polsce sprawa ta nie została w sposób instytucjonalny uregulowana.

Postulaty na przyszłość w tym względzie są następujące:

1. Należy przeprowadzić $w$ poszczególnych oddziałach starych druków ewidencję cymeliów.

2. Równolegle $z$ ewidencją wskazane jest systematyczne mikrofilmowanie cymeliów celem ich zabezpieczenia w formie reprodukcji oraz - częściowego przynajmniej - wyłączenia z użytku.

3. Trzeba wyposażyć stacje mikrofilmowe w lepszej jakości sprzęt reprograficzny taki, który nie narażałby reprodukowanych egzemplarzy starych druków na pogarszanie ich stanu zachowania.

4. Pilną sprawa jest przeprowadzenie $w$ poszczególnych egzemplarzach starych druków ewidencji map i sztychów, co umożliwi lepszą ich kontrolę i tym samym, w znacznym stopniu, ograniczy ich kradzieże.

5. Należy rozpowszechniać zasadę wypożyczania mikrofilmów w miejsce oryginałów druków w wypożyczaniu międzybibliotecznym.

6. Trzeba stworzyć lepsze warunki dla popularyzowania starych druków, szczególnie wśród młodzieży szkolnej, poprzez prelekcje, wystawki stałe lub okolicznościowe oraz wystawy tematyczne.

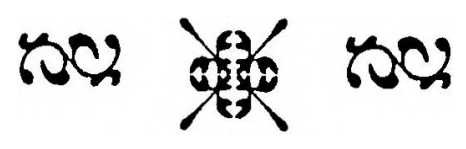

Przypisy:

1 Przykładowo Biblioteka Zakladu Narodowego im. Ossolińskich wg informatora z 1992 r. posiada 76246 woluminów, a wg zestawienia Biblioteki Narodowej z 1978 r. 75728 woluminów. - K. Korzon: Biblioteka Ossolineum we Wroctawiu. Wroclaw 1992, s. 29; Natomiast Biblioteka Jagiellońska w 1993 r. przyznaje się do niższej liczby woluminów starych druków (105000) niż wykazuje zestawienie Biblioteki Narodowej (112 000). Liczba 105000 woluminów została podana przez kierownika Oddziału Starych Druków Biblioteki Jagiellońskiej w rozmowie telefonicznej.

"Biblioteka Gdanska P.A. Izieje i zhiom. Red. M. Babnis. Z. Nowak. Wroclaw 1986. 5. 87-100, Biblioteka (niwersytecka "Warsawie Przewodnik. Red. A. Sapicj. War- 
szawa 1979, s. 50-55; A. Chyczewska, S. Weyman: Zamek Kórnicki . Muzeum i biblioteka. Przewodnik. Wyd. 5. Poznań 1977, s. 69-70; A. Klossowski: Biblioteka Narodowa w Warszawie. Zbiory i dziatalność. Warszawa 1990, s. 70-76; B. Kocowski: Biblioteka Uniwersytecka we Wroctawiu. Wrocław 1968, s. 38-47; Z. Kowalski, J. Olczak: Biblioteka Główna Uniwersytetu Marii Curie Skłodowskiej w Lublinie. Przewodnik. Lublin 1980, s.49-55; Ksiqżnica Miejska im. M. Kopernika (Toruń). Informator. Oprac. A. Tujakowski. Toruń 1983, s. 22-27; Pięćdziesią lat Biblioteki Narodowej Warszawa 1928-1978. Warszawa 1984, s. 159-176; A. Stachurska: Przewodnik po Bibliotece. Jak korzystać ze zbiorów. Szczecin 1980, s. 20-21; I. Turowska-Barowa: Przewodnik po Bibliotece Jagielloniskiej. Kraków 1964, s. 53-60; M. Wilczyńska: Biblioteka Uniwersytetu Marii Curie Sklodowskiej w Lublinie 1944-1974. Lublin 1976, s. 70-72; Zbiory specjalne Biblioteki Uniwersyteckiej w Poznaniu. Informator pod red. K. Michałowskiego. Poznań 1983, s. 7-13.

${ }^{3}$ A. Lewicka-Kamińska: Narastanie zasobu starych druków Biblioteki Jagiellonskiej. Przegląd Biblioteczny 1964, R. 32. z. 4, s. 209-218: J.Z. Lichański: Zbiory specjalne Biblioteki Narodowej. Stan i perspektywy. Przegląd Biblioteczny 1984, R. 52, z. 3/4, s. 333-341; A. Skura: Zbiór starych druków Biblioteki Uniwersyteckiej we Wroctawiu jako źródto do badań nad dziejami ksiqzzki na Ślasktu. W: Studia o ksiqżce 1988 T. 17. S. 191-205. K. Niklewiczówna: Oddzial Starych Druków Biblioteki Uniwersyteckiej w Warszawie 1949-1977. W: Z Badań Nad Polskimi Księgozbiorami Historycznymi. Z. 8. Zbiory specjalne. Warszawa 1985, s. 5-60.

${ }^{4}$ W. Dziechowska: Zbiory specjalne (tzw. tradycyjne) w bibliotekach naukowych Szczecina. W: Bibliotekarstwo na Pomorzu Szczecinskim 1945-1985. Materiały z konferencji pod red. T. Jasińskiej i W. Michnala. Szczecin 1986, s. 122-129; M. Muszyński: Struktura organizacyjna i zadania dzialów starych druków. W: Materiaty biblioteczne z konferencji organizowanych w latach $1963-1968$ przez Biuro Wydawnictw i Bibliotek PAN. Wroclaw 1971, s. 279-299; H. Szwejkowska: Problemy starych druków w polskich bibliotekach naukowych. W: II Konferencja Naukowa Komisji Bibliografii i Bibliotekoznawstwa Wroctawskiego Towarzystwa Naukowego. Wroclaw 1957, s. 97-114; J.Z. Lichański: Zadania Biblioteki Narodowej w' zakresie prac badawczvch i bibliograficznych ze zbiorami cimeliow. Przeglad dotychczasowych dokonan. W: Prace badawcze i bibliograficzne nad zbiorami rzadkich $i$ cennych ksiqżek $i$ dokumentów. Materiaty z Seminarium polsko-radzieckiego. Warszawa 8-10.X.1985 r. Warszawa 1991, s. 19-30; P. Buchwald-Pelcowa: Zadania badawcze i bibliograficzne Biblioteki Narodowej w zakresie starych druków. W: Prace badawcze i bibliograficzne.... s. 31-39.

${ }^{5}$ Wyjątek stanowi referat o formach pracy z czytelnikiem w Bibliotece Kórnickiej PAN - M. Olszewska: Praca z czvtelnikiem w bibliotece naukowej. W: Materiahy biblioteczne..., s. 189-198. Natomiast M. Muszyński przedstawia tylko udostępnianie zbiorów czytelnikom poza bibliotekę - M. Muszyński: Udostępnianie zbiorów w humanistycznych bibliotekach naukowych. W: Materiaty biblioteczne..., s. 199-218.

${ }^{6}$ Problematykę te podjęla jedynie $Z$. Walcry: O dawnvch $i$ wspótczesnych sposobach chronienia ksiazek przed kradzieza. Rocmniki Bibliotecnnc 1976. R. 20. 2. 3/4. S. $8+1-855$. 
${ }^{7}$ Przykładowo wymienić można: H. Lülfing: Handschriften, Inkunabeln, alte vertvolle Bücher. Ihre Tradition und Pflege in den wissenschaftlichen Bibliotheken der DDR. Zentralblatt für Bibliothekswesen 1964, R. 78, z. 11, S. 641-655; E.M. Stelzer: Die Aufgaben der Abteilung für seltene und kostbare Drucke der Deutschen Staatsbibliothek Berlin. Zentralblatt für Bibliothekswesen 1982, R. 96, z. 5, s. 233-238; E.M. Stelzer: Aus der Arbeit für seltene und kostbare Drucke. Zentralblatt für Bibliothekswesen 1986, R. 100, z. 9, s. 403-406: L.N. Petrova: O formirovanii i sochrannosti fondov redkich knig respublikanskich bibliotek. Sovetskoe Bibliotekovedenie 1980, nr 4, s. 82-90.

${ }^{8}$ Dr Hartmut Weber z Krajowej Dyrekcji Archiwów w Baden - Württemberg wyglosil 28.X.1992 r. w Monachium odczyt pt. Verfilmungs-projekte dotyczący przeprowadzania mikrofilmowania zbiorów w celu ich zabezpieczenia. - Maszynopis powielany. Thum. B. Paczyńska-Lahme. Tekst niemiecki pochodzi z niemiecko-polskiej konferencji zorganizowanej w Monachium w dniach 28-31.X.1992 r. na temat: Możliwości zabezpieczania ważnych dla obu krajów dóbr piśmiennictwa wczesnej erv nowożytnej znajdujacych się $w$ zbiorach bibliotek polskich. W'spólne europejskie dziedzictwo w kulturze polskiej i niemieckiej.

9 Wyjątkiem jest Staatsbibliothek w Berlinie, gdzie oddzial muzykaliów powstal już w 1828 r. - W. Mincer, K. Podlaszewska: Zbiory specjalne jako warsztat pracy naukowej. Zeszyty Naukowe Uniwersytetu M. Kopernika w Toruniu. Nauki Humanistyczne-Społeczne z. 29, Nauka o książce 5, 1968, s. 12.

${ }^{10}$ H. Więckowska, H. Pliszczyńska: Podręczny slownik bibliotekarza. Warszawa 1955, s. 191.

${ }^{11}$ W. Mincer, K. Podlaszewska, op. cit., s. 5.

${ }^{12}$ Encyklopedia wspótczesnego bibliotekarstwa polskiego. Wroclaw 1976, s. 321.

${ }^{13}$ Lexikon des Bibliothekswesen. Leipzig 1975. T. 2, szp. 1243-1244.

${ }^{14}$ L.M. Harrod: Harrod's librarians ' glossary of terms used in librarianship, documentation and the book crafts and reference book. Compiled by Ray Prytherch. 7th ed. 1990, s. 581.

${ }_{15}^{15}$ M. Rehm: Lexikon Buch - Bibliothek - neue Medien. München, Paris 1991, s. 253.

${ }^{16}$ J.Z. Lichański: Zadania Biblioteki Narodowej..., s. 25.

${ }^{17}$ Por. J.Z. Lichański: Zadania Biblioteki Narodowej..., s. 20; A. Kłossowski: Biblioteka Narodowa w Warszawie..., S. 201.

${ }_{18}^{18}$ Encyklopedia wiedzy o ksiażce. Wroclaw 1971, szp. 2225.

${ }^{19}$ Encyklopedia wspólczesnego bibliotekarstwa..., s. 90.

${ }^{20}$ Ibidem, s. 298.

${ }^{21}$ R. Cave: Rare book librarianship. London 1976.

${ }^{22}$ A. Kurkowa: Biblioteka Królewska i jej zbiory specjalne. Bibliotekarz 1981, R. 48, nr 5, s. 117.

${ }^{23}$ Encyclopedia of Library and Information Science. New York 1975. T. 15, s. 82.

${ }^{24}$ The Rare Book Division of the Library of Congress. A guide to its collections and service. Washington 1965. s. 25

Ibidem. s. 25. 
${ }^{26}$ L. Nemirovskij: Aktual 'nye problemv raboty z redkimi izdanijami. Sovetskoe Bibliotekovedenie 1980, nr 4, s. 71-82.

${ }^{27}$ Nemirovskij odsyla do pracy A.I. Malein, N.G. Fleer: O redkoj knige. Moskva 1923.

${ }^{28}$ Swój profil gromadzenia zbiorów w dziale książki rzadkiej Rosyjska Państwowa Biblioteka określila w licznych instrukcjach, m.in. Profil' komplektovanija Otdela redkich knig i special'nych proizvedenij pečati. W: Osnovnye položenija i instrukcii Gosudarstvennoj ordena Lenina biblioteki SSSSR im. V.I. Lenina. Moskva 1957. s. 162-165 czy Profil' komplektovanija fonda cennych i redkich izdanij. W: Profili komplektovanija fonda Gosudarstvennoj biblioteki SSSR im. V.I. Lenina inostrannym pečatnymi izdanijami. Moskva 1977, s. 39-43.

29 E.M. Stelzer: Die Aufgaben der Abteilung für seltene und kostbare Drucke der Deutschen Staatsbibliothek. Marginalien. Zeitschrift für Buchkunst und Bibliophile 1979 , z. 76 , s. 14.

${ }^{30}$ E.M. Stelzer: Die Aufgaben dex Abteilung für seltene und kostbare Drucke..., s. 234.

${ }^{31} \mathrm{Na} 74$ Deutscher Bibliothekartag zorganizowanym w dniach 12-16 czerwca $1984 \mathrm{r}$. w Bielefeld, Wolfgang Dittrich z Wolfenbüttel wyglosil referat: Doświadczenia $i$ problemv przy udostępnianiu zasobów pozostajacych pod szczególna ochronq. Natomiast w dniach 21-22 października 1985 r. odbyla się w Staatsbibliothek Preussischer Kulturbesitz Berlin sesja na temat Technika biblioteczna druków rzadkich i cennych.

${ }^{32}$ Komission des Deutschen Bibliotheksinstituts für Handschriften und das alte Buch, Empfehlungen zur Verwaltung alter und vertvoller Buchbestände und zur Organisation von Rarasammlungen. Bibliotheksdienst 1983, R. 17, z .6, s. 496-507.

${ }^{33}$ J.Z. Lichański: Zbiory specjalne Biblioteki Narodowej, s. 340.

${ }^{34} \mathrm{Z}$ odpowiedzi na ankietę.

${ }^{35}$ Przykładowo w 1981 r. w naszej Bibliotece Uniwersyteckiej we Wroclawiu skradziono trzy cenne druki wlaśnie z klocków. Dodajmy, że zlodziej dokładnie z.nał ogromną wartość rynkową kradzionych dziel.

${ }^{36}$ T. Zarzębski: Przepisy prawne dla bibliotek naukowych i fachowych wedlug stanu w dniu 1.VI.1968. Warszawa 1968, s. 350.

${ }^{37}$ Ibidem, s. 53.

${ }^{38}$ Ibidem, s. 54.

${ }^{39}$ Patrz: Ustawa o bibliotekach z dnia 9 kwietnia 1968 r. (Dz.U. nr 12, poz. 63, art. 15 punkt 2-3).

${ }^{40}$ Monitor Polski nr 12, poz. 54, s. 98.

${ }^{41}$ Zasady wypożyczania zbiorów specjalnych Biblioteki Narodowej. Zalącznik nr 1 do zarządzenia nr 23/87 dyrektora Biblioteki Narodowej z dnia 28 września 1987 r., s. $3-5$. 